Click here to download Manuscript: Yakymchuk_et_al_GSAB-R2.docx

Paleozoic evolution of western Marie Byrd Land, Antarctica

1 Paleozoic evolution of western Marie Byrd Land, Antarctica

Chris Yakymchuk ${ }^{\dagger}$

Caitlin R. Brown

Michael Brown

Laboratory For Crustal Petrology, Department of Geology, University of Maryland, College

Park, Maryland 20742, USA

Christine S. Siddoway

Department of Geology, The Colorado College, Colorado Springs, Colorado 80903, USA

C. Mark Fanning

13 Research School of Earth Sciences, The Australian National University, Mills Road, Canberra

14 ACT 0200, Australia

Fawna J. Korhonen

${ }^{\dagger}$ Current address: Department of Earth and Environmental Sciences, University of Waterloo, 200 University Avenue West, Waterloo, Ontario, N2L 3G1, Canada. email: cyakymchuk@uwaterloo.ca

Keywords: Antarctica, Hf and O isotopes, zircon, granite, Gondwana

\title{
25 ABSTRACT
}

26 We report geochemical data from (meta-)sedimentary and igneous rocks that crop out in the Ford

27 Ranges of western Marie Byrd Land and discuss the evolution and reworking of the crust in this

28 region during Paleozoic subduction along the former Gondwanan convergent plate margin.

29 Detrital zircon age spectra from the Swanson Formation, a widespread low-grade metaturbidite

30 sequence, define distinct populations in the late Paleoproterozoic, late Mesoproterozoic and

31 Neoproterozoic-Cambrian. The late Paleoproterozoic group records magmatism derived from a

32 mixed juvenile and crustal source. By contrast, the late Mesoproterozoic group yields Hf isotope

33 values consistent with derivation from a juvenile Mesoproterozoic source inferred to be an

34 unexposed Grenville-age orogenic belt beneath the East Antarctic ice sheet. For the

35 Neoproterozoic-Cambrian population, Hf isotope values indicate reworking of these older 
materials during Ross-Delamerian orogenesis. New U-Pb ages from the Devonian-

37 Carboniferous Ford Granodiorite suite across the Ford Ranges reveal an extended period of arc

38 magmatism from 375 to 345 Ma. For four younger samples of Ford Granodiorite, Hf and O

39 isotope values in zircon suggest involvement of a larger (meta-)sedimentary component in the

40 petrogenesis than for two older samples. This contrasts with the secular trend towards more

41 juvenile values documented from Silurian to Permian granite suites in the Tasmanides of eastern

42 Australia and Famennian to Tournasian granite suites in New Zealand, pieces of continental crust

43 that were once contiguous with western Marie Byrd Land along the Gondwana margin. The

44 differences may relate to an along-arc change from the typical extensional accretionary mode in

45 eastern Australia to a neutral or an advancing mode in West Antarctica, and to an across-arc

46 difference in distance from the trench between the New Zealand fragments of Zealandia and

47 western Marie Byrd Land. Upper Devonian anatectic granites in the Ford Ranges most likely

48 record reworking of early Ford Granodiorite suite members during arc magmatism.

\section{INTRODUCTION}

51 The former continental margin of Gondwana represents one of the most long-lived and

52 extensive active convergent plate margins in the Phanerozoic (e.g. Cawood, 2005; Collins et al.,

53 2011; Harley et al., 2013). Information about the evolution and reworking of the East

54 Gondwanan segment is recorded in the geology and geochemistry of the sedimentary, igneous

55 and metamorphic rocks that crop out in different regions that were once contiguous (Fig. 1A),

56 including: the Tasmanides of Eastern Australia; the Western Province of New Zealand; north

57 Victoria Land; Marie Byrd Land; the Antarctic Peninsula; and the western margin of South

58 America. The New Zealand-Antarctica segment of the former active margin links the geology of 
59 eastern Australia to the east (present co-ordinates) to that of the Antarctic Peninsula and South

60 America to the west (present co-ordinates). The relatively well-understood Tasmanides in eastern

61 Australia represent the type example of an extensional accretionary orogen (Collins, 2002).

62 However, it is of interest to know how the tectonic evolution of this margin might have changed

63 along strike to the west. In Antarctica, the relatively simple Paleozoic tectonic history of western

64 Marie Byrd Land, compared to north Victoria Land (e.g. Borg et al., 1986), makes Marie Byrd

65 Land an ideal location for characterization of the Paleozoic history of the Marie Byrd Land-

66 Zealandia portion of the East Gondwana accretionary margin. Well-substantiated ties between

67 Marie Byrd Land-Zealandia and Zealandia-Australia span the Paleozoic and Mesozoic

68 (Bradshaw et. 1997; Ireland et al. 1998; Wandres and Bradshaw, 2005; Adams, 2010); hence this

69 study contributes significant new data with bearing on the integrated margin. Thus, the results of

70 the study we report herein enable a comparison with the well-characterized evolutionary history

71 of eastern Australia and with recently published data from the formerly contiguous parts of New

72 Zealand.

73 The scarcity of outcrop and difficulty of access in West Antarctica due to the extensive ice

74 cover has limited our understanding of the geology of Marie Byrd Land. Based on a few

75 pioneering studies (Pankhurst et al., 1998; Mukasa and Dalziel, 2000), the tectonic history of this

76 region has been inferred from the geochemistry and geochronology of (meta-)sedimentary and

77 igneous rocks exposed as isolated peaks. Outstanding issues to be addressed in western Marie

78 Byrd Land include: 1) the provenance of Cambrian-Ordovician (meta-)sedimentary rocks; 2) the

79 duration of Devonian-Carboniferous magmatism, which is mostly constrained at present by

80 whole-rock $\mathrm{Rb}-\mathrm{Sr}$ isochron ages; and, 3) the petrogenesis of the Devonian-Carboniferous Ford 
81 Granodiorite suite and associated diatexite (anatectic granite that includes transported residue)

82 and granite.

83 In this study we report geochemical data from detrital zircons from the Cambrian-

84 Ordovician Swanson Formation and related paragneisses, and for whole rocks and zircons from

85 the Devonian-Carboniferous Ford Granodiorite suite and associated diatexite and granite to

86 investigate crustal evolution and reworking in western Marie Byrd Land. First, we use the U-Pb

87 and Hf isotope values of detrital zircon to evaluate the provenance of Cambrian-Ordovician

88 metasedimentary rocks in the Ford Ranges. Second, we couple zircon and whole-rock

89 geochemical information to constrain the duration and petrogenesis of the Ford Granodiorite

90 suite magmatism and associated diatexite and granite. This new study validates the petrogenetic

91 model proposed by Yakymchuk et al. (2013a) in which the Upper Devonian diatexite and granite

92 are the product of partial melting of both the Swanson Formation and the Ford Granodiorite

93 suite. Finally, we combine this new information with data from the literature from

94 contemporaneous magmatic suites along the former continental margin of Gondwana to address

95 the similarities and differences in the proportion of crustal growth to crustal reworking along a

96 Phanerozoic convergent plate margin system.

\section{REGIONAL GEOLOGY}

Marie Byrd Land in West Antarctica (Fig. 1B) was once contiguous with the Western

100 Province of New Zealand, north Victoria Land, and the Tasmanides of eastern Australia prior to

101 the breakup of the active continental plate margin of Gondwana during the Upper Cretaceous

102 (Fig. 1A). Based on Nd model ages of granites, Pankhurst et al. (1998) divided Marie Byrd Land

103 into the Ross Province in the west and the Amundsen Province in the east. The boundary

104 between the two provinces is unexposed and is believed to be oblique to the present coastline 
105 (Fig. 2; DiVenere et al., 1995; Pankhurst et al., 1998). Paleomagnetic data suggest that these two 106 provinces were amalgamated in the Cretaceous (DiVenere et al., 1995; Luyendyk et al., 1996) 107 prior to the separation of Zealandia from West Antarctica (Fig. 1A).

108 In the Ford Ranges of the Ross Province (Fig. 1A, B), the Neoproterozoic-Cambrian 109 Swanson Formation is the oldest exposed unit (Bradshaw et al., 1983; Pankhurst et al., 1998;

110 Adams, 1986, 2004). It is a folded and cleaved metaturbidite sequence that accumulated 111 outboard of the Cambrian Ross-Delamerian orogen. In a regional context, based on the 112 similarity of $\mathrm{U}-\mathrm{Pb}$ ages of detrital zircons, the Swanson Formation has been correlated with the 113 Robertson Bay Group in north Victoria Land and the Greenland Group in the Western Province 114 of New Zealand (Ireland et al., 1998; Adams et al., 2013). Paleocurrent data from the Swanson 115 Formation has been interpreted to suggest flow predominantly towards the North (Bradshaw et 116 al., 1983), indicating a source terrain to the south.

117 The Swanson Formation is intruded by the Devonian-Carboniferous Ford Granodiorite 118 suite, which was associated with a major pulse of Paleozoic calc-alkaline magmatism along the 119 length of the Antarctica-Zealandia-Australia segment of the Gondwanan continental margin 120 (Weaver et al., 1991; Weaver et al., 1992; Muir et al., 1994; Storey et al., 1999; Mukasa and 121 Dalziel, 2000) that has been variously attributed to subduction (Weaver et al., 1991) or back-arc 122 extension (Muir et al., 1996; Tulloch et al., 2009). Rb-Sr whole-rock geochronology from the 123 Ford Granodiorite suite yielded ages of 380-353 Ma (Adams, 1987). U-Pb ages of ca. 375 and $124373 \mathrm{Ma}$ from two Ford Granodiorite suite samples have been used to argue that this magmatism 125 represented only a short-lived pulse of activity (Pankhurst et al., 1998; Yakymchuk et al., 126 2013a). A broader span for magmatic activity is suggested by U-Pb SHRIMP zircon ages of 127 369-353 Ma for granites within the Fosdick migmatite-granite complex (Fig. 2, inset; Siddoway 
128 and Fanning, 2009) and U-Pb monazite ages of ca. 359 and 351 Ma for two-mica granites

129 (Tulloch et al., 2009). A syenogranite sample from Bruner Hill on the Ruppert coast sampled

130 close to the inferred boundary between the Ross and Amundsen Provinces yielded a U-Pb age of

$131339 \pm 6 \mathrm{Ma}$ (Pankhurst et al., 1998). However, it has remained unclear if these data sampled

132 short-lived magmatic pulses or a protracted magmatic history during the Devonian-

133 Carboniferous. Contemporaneous magmatism is recorded in the Admiralty Intrusives of north

134 Victoria Land (390-350 Ma; Borg et al., 1986; Fioretti et al., 1997), the Karamea suite in the

135 Western Province of New Zealand (371-305 Ma; Tulloch et al., 2009), and in the Melbourne

136 terrane in the Tasmanides of Eastern Australia (ca. 360 Ma; Chappell et al., 1988).

137 In the Amundsen Province of eastern Marie Byrd Land, Cambrian metasedimentary rocks

138 appear to be absent and magmatism occurred in the Ordovician-Silurian (450-420 Ma) and in

139 the Permian (ca. 276 Ma; Pankhurst et al., 1998). Granites in the Amundsen Province yield

140 younger $\mathrm{Nd}$ model ages $(1.3-1.0 \mathrm{Ga})$ than granites from the Ross Province $(1.5-1.3 \mathrm{Ga}$;

141 Pankhurst et al., 1998), which, together with the paleomagnetic evidence (DiVenere et al., 1995;

142 Luyendyk et al., 1996), provided the basis for the subdivision of Marie Byrd Land.

143 Within the Ford Ranges of western Marie Byrd Land (Fig. 1B), the Fosdick Mountains

144 expose a migmatite-granite complex (Fig. 2, hereafter the Fosdick complex). Paragneisses and

145 orthogneisses within the Fosdick complex are interpreted as the high-grade metamorphosed

146 equivalents of the Swanson Formation and the Ford Granodiorite suite, respectively (Richard et

147 al., 1994; Siddoway and Fanning, 2009; Korhonen et al., 2010a, b; Yakymchuk et al., 2013a, b,

148 2015). Based on phase equilibria modeling, $\mathrm{U}-\mathrm{Pb}$ ages of monazite and $\mathrm{Lu}-\mathrm{Hf}$ ages of garnet,

149 two metamorphic events have been documented in the Fosdick complex, one in the Devonian-

150 Carboniferous and a higher-grade overprint in the Cretaceous (Korhonen et al., 2010b, 2012; 
151 Yakymchuk et al., 2015). Hf and O isotope compositions of zircons from Devonian-

152 Carboniferous granites in the Fosdick complex indicate that they represent a binary mixture

153 sourced from Ford Granodiorite suite and Swanson Formation components (Yakymchuk et al.,

154 2013a). In contrast, $\mathrm{Hf}$ and $\mathrm{O}$ isotope compositions of zircons from Cretaceous granites indicate

155 input from an unexposed juvenile source in addition to the crustal sources. In general, both the

156 Devonian-Carboniferous and Cretaceous granites in the Ross Province have more evolved Hf

157 isotope values than granites from correlative localities across the Gondwanan margin, including

158 the Western Province of New Zealand and the Tasmanides in eastern Australia. Yakymchuk et

159 al. (2013a) interpreted this difference to record a larger proportion of crustal reworking in the

160 Ross Province compared with a higher proportion of crustal growth in the Western Province and

161 the Tasmanides.

162

163 ANALYTICAL METHODS

164 A detailed description of analytical methods together with Tables DR1-DR9 listing

165 sample locations and the complete analytical data set are available from the GSA Data

166 Repository. Zircon mineral separates were obtained from bulk rock samples using standard

167 crushing, magnetic, and heavy liquid separation methods in the mineral separation facility at the

168 University of Maryland; zircons were mounted in epoxy disks. The zircons were imaged in

169 transmitted light and studied using a cathodoluminescence detector to characterize the internal

170 zoning of each zircon and to avoid analysis of inclusions

171 Four Ford Granodiorite suite samples from outside the Fosdick complex in western Marie

172 Byrd Land and two diatexites from inside the Fosdick complex (Table 1, Fig. 2) were selected

173 for zircon $\mathrm{U}-\mathrm{Pb}, \mathrm{O}$, and $\mathrm{Lu}-\mathrm{Hf}$ isotope analysis at the Research School of Earth Sciences 
174 (RSES), Australian National University following the protocol given in Yakymchuk et al.

175 (2013a). U-Pb isotope ratios were measured with a SHRIMP-II, oxygen isotope ratios were

176 measured with a SHRIMP-II or SHRIMP-SI, and Lu-Hf measurements were conducted by laser

177 ablation multi-collector inductively coupled plasma mass spectroscopy (LA-MC-ICPMS) using

178 the RSES Neptune MC-ICP-MS coupled with a HelEx 193 nm ArF Excimer laser.

179 Detrital zircons from two Swanson Formation samples and igneous zircons from two

180 Ford Granodiorite suite samples from outside the Fosdick complex in western Marie Byrd Land,

181 as well as zircons from three paragneisses from outside the Fosdick complex, and two diatexites

182 and one granite from inside the complex (Table 1, Fig. 2) were analyzed for U-Pb LA-MC-

183 ICPMS geochronology at the University of Arizona Laserchron facility following the protocol

184 outlined in Gehrels et al. (2008). Common Pb correction was accomplished by using Hg-

185 corrected ${ }^{204} \mathrm{~Pb}$ and assuming an initial $\mathrm{Pb}$ composition from Stacey and Kramers (1975). For the

186 two Swanson Formation samples, Lu and Hf isotopes were also measured in zircon at the

187 University of Arizona Laserchron facility following the procedure described in Cecil et al.

188 (2011). The analyses involve ablation of zircon with a New Wave DUV193 Excimer laser while

189 isotope ratios were measured with a $\mathrm{Nu} \mathrm{MC}-\mathrm{ICPMS}$.

190 Strontium, $\mathrm{Rb}, \mathrm{Nd}$ and $\mathrm{Sm}$ isotope compositions for five whole-rock samples of the

191 Swanson Formation, six whole-rock samples of the Ford Granodiorite suite, and three Devonian-

192 Carboniferous granites (Table 1, Fig. 2) were acquired at the University of Maryland using

193 isotope dilution TIMS or ICP-MS following the procedure outlined in Korhonen et al. (2010a).

194 Eight Swanson Formation samples were selected for whole-rock oxygen-isotope analysis at the

195 University of Wisconsin using laser fluorination (Valley et al., 1995). 


\section{SAMPLE DESCRIPTIONS AND U-Pb RESULTS}

\section{Detrital zircons from the Swanson Formation samples and the paragneisses}

Representative cathodoluminescence (CL) images of zircons from two Swanson Formation samples and the paragneisses from the Ford Ranges and Scott Nunataks, including data for one sample reported previously in Yakymchuk et al. (2013a), together with a sample from the Swanson Mountains (Fig. 2) from Adams et al. (2013), are plotted as histograms and normalized probability distributions in Figure 3A-F. In addition, the ages of inherited grains (interpreted as $>400 \mathrm{Ma}$ ) in the Ford Granodiorite suite, the Devonian-Carboniferous granites and the diatexites are plotted in Figure 3G.

Sample Y2-MD092, from Mount Dolber in the Sarnoff Mountains (Fig. ), is a thinly bedded metagreywacke with a foliation defined by the parallel alignment of biotite. Zircon $\mathrm{U}-\mathrm{Pb}$ dates range from ca. 440 to ca. $3030 \mathrm{Ma}$ with distribution peaks at 554, 1048 and $1763 \mathrm{Ma}$ (Fig. 3B). The youngest group of four dates that overlap at $\sigma$ yields a weighted mean age of $489 \pm 14$ Ma.

Sample Y2-MP098, from Mount Passel in the central Ford Ranges (Fig. ), is a poorly sorted metagreywacke containing angular clasts of quartz, feldspar and volcanic rock fragments in a fine-grained matrix. Zircon U-Pb dates range from ca. 510 to ca. $2800 \mathrm{Ma}$ with distribution peaks at 577, 1037 and $1725 \mathrm{Ma}$ (Fig. 3C). The youngest group of four dates that overlap at $\sigma$ yields a weighted mean age of $514.0 \pm 4.8 \mathrm{Ma}$.

Sample 8D27-10 is a calc-silicate gneiss from Mt Woodward in the Ford Ranges (Yakymchuk et al., 2013a). Zircon U-Pb dates range from ca. 500 to ca. $3490 \mathrm{Ma}$ with peaks at 570, 1096, and $1736 \mathrm{Ma}$ (Fig. 3D). The youngest group of four dates that overlap at $\sigma$ yields a 
220 221

222

223

224

225

226

227

228

229

230

231

232

233

234

235

236

237

238

239

240

241

242

weighted mean age of $532.5 \pm 5.3 \mathrm{Ma}$.

Sample 318-M9 is a folded biotite-paragneiss from Mitchell Peak on the Guest Peninsula (Fig. 2). Zircon U-Pb dates range from ca. 330 to ca. 2460 Ma with distribution peaks at 548, 1084 and $1704 \mathrm{Ma}$ (Fig. 3E). The youngest group of four dates that overlap at $\sigma$ yields a weighted mean age of $509 \pm 17 \mathrm{Ma}$.

Samples 21220-3 and 21220-8 are paragneisses from Scott Nunataks (Smith, 1996). Both samples were collected from the same outcrop, so the age data sets are pooled. Dates range from ca. 110 to ca. 2660 Ma with distribution peaks at 533, 1085, and $1611 \mathrm{Ma}$ as well as a small peak at ca. $412 \mathrm{Ma}$ (Fig. 3F). The youngest group of four dates that overlap at $\sigma$ yields a weighted mean age of $387 \pm 22 \mathrm{Ma}$.

In summary, individual $\mathrm{U}-\mathrm{Pb}$ dates for detrital zircons from the Swanson Formation range from ca. 440 to ca. $3030 \mathrm{Ma}$ (Fig. 3A-C); zircons from the paragneisses have similar age distributions, but with a few younger dates (Fig. 3D-F). Although Archean grains are present, they make up only a minor portion of the population. The dominant zircon population in Swanson Formation and paragneiss samples is Neoproterozoic-Cambrian, with dates ranging from ca. 500 to ca. $750 \mathrm{Ma}$ and age peaks at 533 and $576 \mathrm{Ma}$ (Fig. 3A-F). The second significant population comprises mostly Mesoproterozoic dates that range from ca. 930 to ca. 1180 Ma with age peaks at 997 and 1096 Ma (Fig. 3A-F). The third and most poorly defined population comprises mostly Paleoproterozoic dates that extend from ca. 1560 to ca. $1930 \mathrm{Ma}$ with age peaks at 1611 and $1763 \mathrm{Ma}$ (Fig. 3A-F). Inherited grains yield a dominant

Neoproterozoic-Cambrian population with some older and younger ages (Fig. 3G).

\section{Ford Granodiorite suite, granites and diatexites}


Representative cathodoluminescence (CL) images of zircons from six Ford Granodiorite

244 suite samples, two diatexite samples and one Upper Devonian granite dated in this study are

245 shown in Figure 4. U-Pb results are reported in Tables DR4-5, plotted on U-Pb Tera-

246 Wasserberg concordia diagrams and as probability distributions (with stacked histograms) in

247 Figure 5. Final ages are summarized in Table 2; these ages are interpreted to date crystallization

248 with the exception of the diatexite (Y1-IG071). For this sample, no statistically significant age

249 was obtained.

\section{MAJOR OXIDE AND TRACE ELEMENT GEOCHEMISTRY}

252 The geochemistry of the samples from this study (supplementary table DR2), combined with 253 geochemical data from Korhonen et al. (2010a) and Weaver et al. (1991, 1992), Pankhurst et al. 254 (1998) and Tulloch et al. (2009) for 15 Ford Granodiorite suite samples, is plotted as a series of 255 Harker diagrams in Figure 6. Normalized rare earth element (REE) patterns are given in Figure 2567.

258 Swanson Formation

259 The Swanson Formation has $\mathrm{SiO}_{2}$ contents ranging from 61 to $74 \mathrm{wt} \%$ (Fig. 6); although 260 variable, individual samples are peraluminous with aluminum saturation indices (ASI= Molar $\left.261\left[\mathrm{Al}_{2} \mathrm{O}_{3} /\left(\mathrm{CaO}+\mathrm{Na}_{2} \mathrm{O}+\mathrm{K}_{2} \mathrm{O}\right)\right]\right)$ of 1.2-2.0, decreasing with increasing $\mathrm{SiO}_{2}$. With increasing $\mathrm{SiO}_{2}$, $262 \mathrm{TiO}_{2}, \mathrm{CaO}, \mathrm{Na}_{2} \mathrm{O}, \mathrm{U}, \mathrm{Th}, \mathrm{Sr}, \mathrm{Ba}$ and $\mathrm{La}$ remain relatively constant, whereas $\mathrm{Al}_{2} \mathrm{O}_{3}, \mathrm{~K}_{2} \mathrm{O}$, $263 \mathrm{FeO}^{*+\mathrm{MgO}}, \mathrm{Rb}$ and $\mathrm{Rb} / \mathrm{Sr}$ decrease, and $\mathrm{Zr}$ increases (Fig. 6). The Swanson Formation has 264 limited variation in REE abundances; individual samples are characterized by normalized 
265 patterns (Fig. 7) that are smooth for the LREE and flat for the HREE, with consistent $\mathrm{La}_{\mathrm{N}} / \mathrm{Lu}_{\mathrm{N}}$ of

$2668-11$ and moderate negative $\mathrm{Eu}$ anomalies $\left(\mathrm{Eu}_{\mathrm{N}} / \mathrm{Eu}_{\mathrm{N}} *=0.6-0.7\right)$.

268 Ford Granodiorite suite

269 The Ford Granodiorite suite has $\mathrm{SiO}_{2}$ contents ranging from 64 to 76 wt \% (Fig. 6);

270 individual samples vary from metaluminous to peraluminous with increasing $\mathrm{SiO}_{2}(\mathrm{ASI}=0.9-$

271 1.2). With increasing $\mathrm{SiO}_{2}, \mathrm{~K}_{2} \mathrm{O}$ and $\mathrm{Th}$ increase, and although $\mathrm{Rb}, \mathrm{Sr}$ and $\mathrm{Rb} / \mathrm{Sr}$ are variable at

$272 \mathrm{SiO}_{2}<71 \mathrm{wt} \%$, at $\mathrm{SiO}_{2}>71 \mathrm{wt} \% \mathrm{Rb}$ increases, Sr decreases and $\mathrm{Rb} / \mathrm{Sr}$ increases (Fig. 6). By

273 contrast, $\mathrm{Al}_{2} \mathrm{O}_{3}, \mathrm{CaO}, \mathrm{FeO}^{*}+\mathrm{MgO}, \mathrm{TiO}_{2}, \mathrm{Zr}$, and $\mathrm{Ba}$ decrease, whereas $\mathrm{Na}_{2} \mathrm{O}$ and La remain

274 relatively constant and $U$ is highly variable (Fig. 6). The Ford Granodiorite suite has a wider

275 range of REE abundances than the Swanson Formation; individual samples have mostly smooth

276 LREE patterns and smooth to concave up HREE (Gd-Lu) patterns (Fig. 7), with $\mathrm{La}_{\mathrm{N}} / \mathrm{Lu}_{\mathrm{N}}$ of 6-

27715 and variable negative Eu anomalies $\left(\mathrm{Eu}_{\mathrm{N}} / \mathrm{Eu}_{\mathrm{N}} *=0.3-0.8\right)$.

279 Devonian-Carboniferous granites and diatexites

280 Devonian-Carboniferous granites have $\mathrm{SiO}_{2}$ contents ranging from 65 to 72 wt \% (Fig.

281 6); they are metaluminous to peraluminous (ASI = 1.0-1.2). Although the geochemistry is

282 variable with increasing $\mathrm{SiO}_{2}$, the granites show decreasing $\mathrm{Al}_{2} \mathrm{O}_{3}, \mathrm{CaO}, \mathrm{FeO}^{*}+\mathrm{MgO}, \mathrm{TiO}, \mathrm{Zr}$

283 and $\mathrm{Ba}$, whereas $\mathrm{K}_{2} \mathrm{O}, \mathrm{U}$, Th, $\mathrm{Rb} \mathrm{Sr}, \mathrm{Rb} / \mathrm{Sr}$ and $\mathrm{La}$ show no trend and $\mathrm{Na}_{2} \mathrm{O}$ increases (Fig. 6).

284 The granites have elevated LREE and depressed HREE relative to the Ford Granodiorite suite;

285 individual samples have smooth LREE patterns and smooth to concave up HREE patterns (Fig.

286 7), with $\mathrm{La}_{\mathrm{N}} / \mathrm{Lu}_{\mathrm{N}}$ of $12-77$ and variable negative Eu anomalies $\left(\mathrm{Eu}_{\mathrm{N}} / \mathrm{Eu}_{\mathrm{N}}{ }^{*}=0.4-0.8\right)$. 
The two diatexites have $\mathrm{SiO}_{2}$ of 72 and $73 \mathrm{wt} \%$; they are both peraluminous (ASI $=1.1$

288

289

290

291

292

293

294

295

296

297

298

299

300

\section{Hf AND O RESULTS}

\section{Sr and Sm-Nd RESULTS}

and 1.2) with $\mathrm{Rb} / \mathrm{Sr}$ ratios $<1$. Sample Y1-IG073 has higher $\mathrm{Zr}$, Th, Ba and La, but otherwise the major oxides and other trace element abundances are comparable to each other (Fig. 6). The diatexites have steep chondrite-normalized REE patterns $\left(\mathrm{La}_{N} / \mathrm{Lu}_{\mathrm{N}}=55\right.$ and 22) with elevated LREE and depressed HREE relative to the Ford Granodiorite suite and negative Eu anomalies $\left(\mathrm{Eu}_{\mathrm{N}} / \mathrm{Eu}_{\mathrm{N}} *=0.5\right.$ and 0.6$)$ similar to those of the granites (Fig. 7).

Newly analyzed samples of the Swanson Formation have ${ }^{87} \mathrm{Sr}^{86} \mathrm{Sr}_{360 \mathrm{Ma}}$ values of 0.7119 0.7204 and $\varepsilon \mathrm{Nd}_{360 \mathrm{Ma}}$ values that range from -9.3 to -6.3 (Fig. 8), whereas newly analyzed samples of the Ford Granodiorite suite have ${ }^{87} \mathrm{Sr}^{86} \mathrm{Sr}_{360 \mathrm{Ma}}$ values of $0.7052-0.7092$ and $\varepsilon \mathrm{Nd}_{360 \mathrm{Ma}}$ values that range from -3.1 to -0.2 (Fig. 8). Two newly analyzed Devonian-Carboniferous granites (Y1-AE035 and M5-G175) have ${ }^{87} \mathrm{Sr}^{86} \mathrm{Sr}_{360 \mathrm{Ma}}$ values of 0.7075 and 0.7091 , and $\varepsilon \mathrm{Nd}_{360 \mathrm{Ma}}$ values of -4.3 and -3.8 , respectively (Fig. 8). A homogenous diatexite (Y1-IG073) has ${ }^{87} \mathrm{Sr}^{86} \mathrm{Sr}_{360 \mathrm{Ma}}$ of 0.7094 and a $\varepsilon \mathrm{Nd}_{360 \mathrm{Ma}}$ value of -4.3 (Fig. 8), whereas an inhomogeneous diatexite (Y1-IG071) has ${ }^{87} \mathrm{Sr}^{86} \mathrm{Sr}_{360 \mathrm{Ma}}$ of 0.7045 and a $\varepsilon \mathrm{Nd}_{360 \mathrm{Ma}}$ value of -5.7 (Fig. 8).

\section{Swanson Formation and calc-silicate gneiss}

$\mathrm{U}-\mathrm{Pb}, \mathrm{Hf}$ and $\mathrm{O}$ data from detrital zircons are plotted in Figure 9. Detrital zircons from sample Y2-MP098 yielded $\varepsilon \mathrm{Hf}_{\mathrm{t}}(\varepsilon \mathrm{Hf}$ calculated at the $\mathrm{U}-\mathrm{Pb}$ age $)$ values that range from -24.5 to 9.7 (Fig. 9A) and roughly half are negative (26 of 45). Sample Y2-MD092 contains detrital zircons with $\varepsilon \mathrm{Hf}_{\mathrm{t}}$ values that range from -13.4 to 8.2 (Fig. 9A), and again approximately half are 
negative (25 of 49).

311 Detrital zircons from sample 8D27-10 (calc-silicate gneiss) define the same U-Pb age

312 populations as samples of the Swanson Formation. Therefore, published data for this sample

313 (Yakymchuk et al., 2013a) have been included in the final data set for the Swanson Formation

314 discussed below. This sample has $\varepsilon \mathrm{Hf}_{\mathrm{t}}$ values that mostly range from -3.7 to +6.0 , with two

315 outlying values of -11.4 and +8.9 (Fig. 9A; Yakymchuk et al., 2013a). The range of $\delta^{18} \mathrm{O}$ values

316 for detrital zircons from the calc-silicate gneiss (8D27-10) is from 6.4 to $10.8 \%$, with one value

317 of $16.6 \%$ (Fig. 9B; Yakymchuk et al., 2013a). Zircons from the Neoproterozoic-Cambrian and

318 Mesoproterozoic populations both have a similar range of $\delta^{18} \mathrm{O}$ values that are between those

319 expected for zircon crystallized from juvenile magmas and those derived solely from a

320 supracrustal source (Fig. 9B).

321 Combining data from the three samples yields a range of $\varepsilon \mathrm{Hf}_{\mathrm{t}}$ values for each of the three

322 age populations, as follows. For the Neoproterozoic-Cambrian population, $\varepsilon \mathrm{Hf}_{\mathrm{t}}$ values mostly lie 323 between -10 and +3 , whereas for the Mesoproterozoic population, most $\varepsilon \mathrm{Hf}_{\mathrm{t}}$ values range from

$324+1$ to +10 . For the Paleoproterozoic population, $\varepsilon \mathrm{Hf}_{\mathrm{t}}$ values vary from -7 to +7 , but most are 325 negative with one value of -17 , and, Archean grains have only negative $\varepsilon \mathrm{Hf}_{\mathrm{t}}$ values that range 326 from -6.1 to -0.4 .

327 For whole-rock oxygen isotope analysis, six of the eight analyzed Swanson Formation 328 samples yielded whole-rock $\delta^{18} \mathrm{O}$ oxygen values that range from +10.0 to +13.5 , which give an 329 average value of +11.9 (GSA Data Repository). Two samples (10CY-001 and 10CY-002) are 330 metasedimentary hornfels collected from the contact aureole of a Cretaceous pluton in the Clark 331 Mountains; these samples yielded whole-rock $\delta^{18} \mathrm{O}$ values of -6.9 and -9.2 , respectively. 


\section{3}

334

335

336

337

\section{Ford Granodiorite suite and diatexite}

The individual $\mathrm{Hf}$ and $\mathrm{O}$ results vs. crystallization age for zircons from the Ford Granodiorite suite and diatexite samples from this study are summarized in Figure 10. Zircons from sample Y2-JU096 have $\varepsilon \mathrm{Hf}_{\mathrm{t}}$ values that range from -4.4 to +1.7 , and $\delta^{18} \mathrm{O}$ values that vary from 7.4 to 9.6 , with weighted means of $-1.6 \pm 1.1$ and $8.8 \pm 0.3$, respectively ( $\sigma ; 13$ of 18 ). Zircons from sample 51225-2 have $\varepsilon \mathrm{Hf}_{\mathrm{t}}$ values that range from -4.5 to +0.4 (with two values of 8.6 and -9.5 ), and $\delta^{18} \mathrm{O}$ values that vary from 8.4 to 10.5 (with two values of 4.6 and 7.5), with weighted means of $-2.1 \pm 1.0$ and $9.5 \pm 0.3$, respectively ( $\sigma ; 15$ of 17 ). Zircons from sample 9N27-4 have $\varepsilon \mathrm{Hf}_{\mathrm{t}}$ values that range from -5.3 to +0.2 , and $\delta^{18} \mathrm{O}$ values that vary from 7.0 to 9.7 , with weighted means of $-3.3 \pm 1.0$ and $7.6 \pm 0.3$, respectively ( $\sigma ; 13$ of 15). Zircons from sample $912-2 \mathrm{~A}$ have $\varepsilon \mathrm{Hf}_{\mathrm{t}}$ values that range from -4.8 to +1.9 (with one value of -13.8), and $\delta^{18} \mathrm{O}$ values that vary from 8.0 to 9.3 (with one value of 7.4), with weighted means of $-1.9 \pm 0.8$ and $8.7 \pm 0.2$, respectively ( $\sigma ; 14$ of 15 ).

The inhomogeneous diatexite (Y1-IG071) yields a wide range of $\mathrm{U}-\mathrm{Pb}$ ages with two dominant populations: Upper Devonian and Cretaceous (Fig. 5). Zircons from the older population have $\varepsilon \mathrm{Hf}_{360}$ values of -9.8 to -1.3 , and $\delta^{18} \mathrm{O}$ values of 9.4 to 10.6 , with weighted means of $-6.9 \pm 2.7$ and $10.0 \pm 0.6$, respectively $(\sigma ; n=6)$. Zircons from the younger population have $\varepsilon \mathrm{Hf}_{100}$ values of -10.0 to -4.7 (one value of -13.5 ), and $\delta^{18} \mathrm{O}$ values of 9.5 to 10.2 (one value of 4.7), with weighted means of $-7.2 \pm 1.2$ and $9.8 \pm 0.2$, respectively ( $\sigma ; 9$ of 10$)$. The homogenous diatexite (Y1-IG073) contains only Upper Devonian zircons that have $\varepsilon \mathrm{Hf}_{\mathrm{t}}$ values of -3.9 to -2.1 , and $\delta^{18} \mathrm{O}$ values of 8.5 to 10.4 , with weighted means of $-3.1 \pm 0.3$ and $9.6 \pm 0.2$, respectively ( $\sigma ; 18$ of 19$)$. 


\section{DISCUSSION}

\section{Possible sources for the Swanson Formation detrital zircons}

The $\mathrm{U}-\mathrm{Pb}$ ages and $\varepsilon \mathrm{Hf}_{\mathrm{t}}$ values from detrital zircons may be used to assess potential sources for each zircon population identified in the Swanson Formation samples, as discussed below. The plausibility of these potential source materials based on $\mathrm{U}-\mathrm{Pb}$ ages and $\varepsilon \mathrm{Hf}_{\mathrm{t}}$ values is

361 evaluated using a $\varepsilon \mathrm{Hf}_{\mathrm{t}}$ evolution plot in Figure 11.

Paleoproterozoic (ca. $1.7 \mathrm{Ga}$ ) zircons from the Swanson Formation have $\varepsilon \mathrm{Hf}_{\mathrm{t}}$ values that

363 range from -7 to +7 , with one value of -17 (Fig. 11). The Nimrod Group, which crops out in the

364 Miller Range of central Transantarctic Mountains (Fig. 1A), includes rocks with zircon of the

365 same age range (Goodge and Fanning, 2002). Igneous zircons from Archean layered gneisses in

366 the Nimrod Group have metamorphic overgrowths dated at 1730-1720 Ma. In addition, a single

367 deformed granodiorite yielded a crystallization age of ca. $1730 \mathrm{Ma}$ (Goodge et al., 2001). This

368 exposure of Precambrian basement in the central Transantarctic Mountains, which is inferred to

369 continue under the ice (Goodge and Finn, 2010), represents a possible source for the

370 Paleoproterozoic and older zircons in the Swanson Formation samples.

371 Most Mesoproterozoic zircons in the Swanson Formation have positive $\varepsilon \mathrm{Hf}_{\mathrm{t}}$ values,

372 suggesting a relatively juvenile source. The gneiss at Haag Nunataks, located to the northeast of

373 the Ellsworth Mountains (Flowerdew et al., 2007), is the only exposure of probable

374 Mesoproterozoic basement in West Antarctica. An Rb-Sr whole-rock isochron age of $1176 \pm 76$

375 Ma was interpreted to date crystallization of the protolith of this gneiss (Millar and Pankhurst,

376 1987). Slightly younger $\mathrm{Rb}-\mathrm{Sr}$ whole-rock isochron ages were obtained from cross cutting

377 microgranite $(1058 \pm 53 \mathrm{Ma})$ and aplogranite and pegmatite $(1003 \pm 18 \mathrm{Ma})$ from this outcrop

378 (Millar and Pankhurst, 1987). For the gneiss, $\varepsilon \mathrm{Hf}_{\mathrm{t}}$ values from zircon range from +6.7 to +9.2 
379 (Flowerdew et al., 2007) and whole-rock $\mathrm{Nd}$ isotope analysis yielded a depleted mantle model 380 age of ca. $1250 \mathrm{Ma}$ (Storey et al., 1994). Taken together, these data suggest that the gneiss at 381 Haag Nunataks represents a relatively juvenile addition to the crust during the Mesoproterozoic, 382 qualifying it as a potential source for this population of detrital zircons.

384 beneath the Antarctic ice sheet. For example, Tochilin et al. (2012) report detrital zircon $\mathrm{U}-\mathrm{Pb}$ age populations of 512-540 Ma and 800-1100 Ma from Oligocene-Quaternary sedimentary rocks in drill core from the Prydz Bay region (Fig. 1A), which is estimated to drain roughly $16 \%$

387 of the East Antarctica Ice Sheet. In addition, direct samples of the bedrock beneath the Antarctic 388 ice sheet are provided by clasts from glacial moraines (e.g. Goodge et al., 2010, 2012). Zircons

389 from granite clasts in Quaternary glacial tills in the Central Transantarctic Mountains yielded $390 \varepsilon \mathrm{Hf}_{\mathrm{t}}$ values of +2 to +6 at ca. $1.2 \mathrm{Ga}$ (Goodge et al., 2013). These clasts suggest the presence of a 391 Mesoproterozoic orogenic belt under the ice inland from the Transantarctic Mountains that has 392 been speculatively linked to the Gamburtsev Subglacial Mountains and the Vostok Subglacial 393 Highlands of East Antarctica (e.g. Elliot et al., 2014).

394 The Mesoproterozoic population of detrital zircons from the Swanson Formation, with 395 the exception of three grains, is younger than both the gneiss at Haag Nunataks (based on the $3961176 \pm 76 \mathrm{Ma} \mathrm{Rb}-\mathrm{Sr}$ isochron age of the gneiss) and the ca. $1.2 \mathrm{Ga}$ granite clast from the Central 397 Transantarctic Mountains (Fig. 11). However, for an average crustal ${ }^{176} \mathrm{Lu} /{ }^{177} \mathrm{Hf}$ ratio (Vervoort 398 and Patchett, 1996; Vervoort et al., 1999), within $\pm 1 \sigma$ uncertainty, the $\varepsilon H f$ evolution lines from 399 these potential sources enclose most of the Mesoproterozoic detrital zircon data from the 400 Swanson Formation samples. This permits the Mesoproterozoic zircons to have been derived 401 from source materials similar to these examples. 
Mesoproterozoic zircons from sample 8D27-10 yielded $\delta^{18} \mathrm{O}$ values above those expected

403 for juvenile material derived directly from the mantle (Fig. 9B), which indicates the involvement

404 of a supracrustal component. This is consistent with crustal reworking during a Mesoproterozoic

405 orogenic event. If these zircon grains were derived from rocks inland of the Transantarctic

406 mountains, which seems likely, the $\delta^{18} \mathrm{O}$ values of the zircons lends support to the existence of

407 Grenville-age orogenic belt exposed beneath the East Antarctic Ice sheet (e.g. Goodge et al.,

408 2010; Elliot et al., 2014).

409 The Neoproterozoic-Cambrian population of zircons from the Swanson Formation

410 contains more evolved $\varepsilon \mathrm{Hf}_{\mathrm{t}}$ values than the Mesoproterozoic population, which is consistent with

411 derivation from igneous and metamorphic rocks associated with crustal reworking in the Ross-

412 Delamerian orogen (Ireland et al., 1998; Adams et al., 2013). In the central Transantarctic

413 Mountains, the oldest intrusive rocks are dated at ca. $550 \mathrm{Ma}$ (Rowell et al., 1993) and

414 widespread magmatism associated with the Ross Orogen is dated at 520-480 Ma (Goodge et al.,

415 2012; Paulsen et al., 2013). In the Wilson Terrane of north Victoria Land, the Granite Harbour

416 Intrusives have been dated at 520-490 Ma (Borg et al., 1986; Vetter et al., 1987; Dallai et al.,

417 2003; Goodge et al., 2012). Although there are no reported $\varepsilon H f$ values for these rocks, some

418 diorites, granites and granodiorites have $\delta^{18} \mathrm{O}$ values consistent with a significant crustal

419 component (Dallai et al., 2003). In the Dry Valleys of south Victoria Land, a minor episode of

420 magmatism at 530-505 Ma was followed by the emplacement of a large volume of calc-alkaline

421 granite at 505-500 Ma (Allibone and Wysoczanski, 2002). However, most zircons from the

422 Neoproterozoic-Cambrian population from the Swanson Formation are older than most igneous

423 and metamorphic rocks reported from the Ross Orogen as described above. Evidence of an older

424 potential source comes from the Central Transantarctic Mountains where glacial clasts in 
425 moraines are inferred to be samples of the subglacial bedrock. These rocks have U-Pb zircon

426 ages of 590-490 Ma (Goodge et al., 2012).

427 Most ages from the Neoproterozoic-Cambrian population of zircons from the Swanson

428 Formation are older than most of igneous rocks from north Victoria Land and the Transantarctic

429 Mountains, with the exception of a ca. 590 Ma glacial clast reported in Goodge et al. (2012).

430 However, most of the Neoproterozoic-Cambrian zircons from the Swanson Formation plot along

431 the same $\varepsilon H f$ evolution lines as the Mesoproterozoic population of detrital zircons discussed

432 above (Fig. 11). This suggests that most of the detrital zircons in the Swanson Formation could

433 have been derived from crust, or sedimentary derivatives of crust, that is similar to the gneiss at

434 Haag Nunataks and the ca 1.2 Ga Mesoproterozoic granite clasts that originated from beneath the

435 East Antarctic ice sheet.

437 Detrital zircon provenance across the former margin of East Gondwana

The three age populations of detrital zircons from the Swanson Formation are broadly

439 consistent with the provenance of Early Paleozoic sediments along the eastern portion of

440 Gondwanan margin, which extended from Australia through West Antarctica and the Antarctic

441 Peninsula into South America (Ireland et al., 1998; Adams et al., 2005; Adams, 2010; Adams et

442 al., 2013). In particular, the detrital zircon patterns of the Swanson Formation are similar to those

443 from the Lachlan Group in eastern Australia, the Robertson Bay Group in North Victoria Land,

444 and the Greenland Group in the Western Province of New Zealand (Ireland et al., 1998; Adams

445 et al., 2013). The maximum depositional ages and the youngest zircon ages are similar for these

446 three groups and the Swanson Formation. In addition, the $\mathrm{U}-\mathrm{Pb}$ age distributions of detrital

447 zircons from the Swanson Formation are similar to those from metasedimentary rocks from the 
448 Trinity Peninsula Group and Fitzgerald Quartzite on the Antarctic Peninsula (Flowerdew et al., 449 2006a; Bradshaw et al., 2012), sedimentary rocks from the Ellsworth-Whitmore Mountains

450 (Flowerdew et al., 2007) and Ross supergroup sandstones in the Queen Maud Mountains

451 (Paulsen et al., 2015).

452 In general, the $\varepsilon \mathrm{Hf}_{\mathrm{t}}$ values of Neoproterozoic-Cambrian and Mesoproterozoic

453 populations of zircons from sedimentary rocks deposited along the East Gondwana margin are 454 similar to those from the Swanson Formation. For example, the Trinity Peninsula Group on the 455 Antarctic Peninsula has detrital zircon age populations of 1100-1000 Ma and 620-500 Ma for 456 which the majority of $\varepsilon \mathrm{Hf}_{\mathrm{t}}$ values from each group range from +2 to +12 and -8 to +2 , 457 respectively (Bradshaw et al., 2012). Flowerdew et al. (2006a) report juvenile Hf isotope values 458 from older zircon populations and less radiogenic Hf isotope values from the dominant (ca. 540 459 Ma) zircon population in the Fitzgerald Quartzite. Neoproterozoic-Cambrian zircons from the 460 Greenland Group in New Zealand yield $\varepsilon \mathrm{Hf}_{\mathrm{t}}$ values of -20 to +8 (Nebel-Jacobsen et al., 2011). 461 Detrital zircon in paragneisses from the Western Province of New Zealand show a similar 462 distribution of ages to the Swanson Formation and yield $\varepsilon \mathrm{Hf}_{\mathrm{t}}$ and $\delta^{18} \mathrm{O}$ values that indicate an 463 increase in the amount of crustal reworking through time (Hiess et al., 2014). Ordovician 464 volcaniclastic rocks deposited on the margin of the Macquarie Arc in the Tasmanides also show 465 negative $\varepsilon \mathrm{Hf}_{\mathrm{t}}$ values for Neoproterozoic-Cambrian zircons and slightly negative to positive 466 values for 1250-970 Ma detrital zircons (Glen et al., 2011).

467 The similarity of $\mathrm{U}-\mathrm{Pb}$ ages and $\mathrm{eHf}_{\mathrm{t}}$ values of detrital zircons from Cambrian468 Ordovician sedimentary rocks deposited across the East Gondwana margin suggest a laterally 469 extensive source region. Neoproterozoic-Cambrian zircons reflect predominantly crustal 470 reworking and likely originated from the Ross-Delamerian orogen and its putative inland 
471 extension beneath the Antarctic ice sheet. The location of an extensive source of relatively

472 juvenile Mesoproterozoic material is more problematic, but the Grenville-age orogenic belt

473 hypothesized to occur beneath the East Antarctic ice sheet is a possible solution.

$475 \delta^{18} \mathbf{O}$ values of the Swanson Formation

476 Sedimentary rocks and granites derived from them can be distinguished from granites

477 with juvenile sources using oxygen isotopes (e g O’Neil and Chappell, 1977). To evaluate the

478 proportional contribution of the Swanson Formation to the petrogenesis of granites in western

479 Marie Byrd Land it is necessary to know the $\varepsilon \mathrm{Hf}_{\mathrm{t}}$ values of the detrital zircon and the $\delta^{18} \mathrm{O}$ values

480 of whole-rock samples. For six of the eight samples of Swanson Formation, whole-rock values

481 range from 10.0 to $13.5 \%$, which are similar to values expected for most sedimentary rocks

482 ( 12\%; O’Neil and Chappell 1977). However, these values are lower than whole-rock values

483 reported for the correlative Greenland Group of 13.7-16.2\%o (Tulloch et al, 009) used by

484 Yakymchuk et al. (2013a) to model mixing of material between the Ford Granodiorite suite and

485 the Swanson Formation. During partial melting, oxygen isotope fractionation between zircon and 486 granitic magma will result in igneous zircons that have $\delta^{18} \mathrm{O}$ values less than the source rock by

487 1-2\%o (Valley et al , 1994; Valley, 2003). Therefore, using a $\Delta^{18} \mathrm{O}_{\mathrm{Zrc}-W R}$ correction of $-15 \%$ for 488 isotope fractionation, newly crystallized zircons in granites derived from partial melting of the 489 Swanson Formation are predicted to have a $\delta^{18} \mathrm{O}$ values of $\sim 8.5-12 \%$.

490 Two Swanson Formation samples from the contact aureole around a Cretaceous pluton 491 show negative whole-rock $\delta^{18} \mathrm{O}$ values of -6.9 and $-9.2 \%$ (GSA Data Repository Table DR7).

492 Negative values are consistent with hydrothermal alteration associated with an active magma 493 chamber at a shallow enough depth to allow the penetration of negative $\delta^{18}$ O meteoric water. A 494 strong isotope exchange between the rocks and meteoric water is needed to produce the negative 
495 isotope values observed in these two samples. Furthermore, the strongly negative $\delta^{18} \mathrm{O}$ values of

496 the meteoric water necessary for hydrothermal alteration of these two Swanson Formation

497 samples are compatible with high latitudes, consistent with the position of western Marie Byrd

498 Land during the Cretaceous (e.g. DiVenere et al., 1994).

500 Petrogenesis of the Ford Granodiorite suite, the granites and the diatexites

501 Temporal changes in Hf and O isotopes in zircon

502 For a fuller assessment of the relationships among the Ford Granodiorite suite, the granites and

503 the diatexites, and due consideration of their petrogenesis, the six new $\mathrm{Hf}$ and $\mathrm{O}$ isotope datasets

504 reported in this study have been combined with published information for four additional

505 samples (from Yakymchuk et al., 2013a; Ford Granodiorite suite samples MB.214.W and

506 MB.219.W, and granite samples M5-G175 and C5-Is51A). The combined dataset is shown as ten

507 box-and-whisker plots for $\varepsilon \mathrm{Hf}_{\mathrm{t}}$ and $\delta^{18} \mathrm{O}$ vs. age in Figure 12. Box-and-whisker plots are used

508 because the data are not normally distributed. These plots provide a graphical summary of

509 dataset characteristics based on percentile rank analysis and plotting the maximum and minimum

510 dataset values. Importantly, the underlying statistics are less sensitive toward individual outliers

511 than other methods of analysis (Tukey, 1977). Also, the compact nature of the plots allows side-

512 by-side comparison of individual sample datasets. Nonparametric statistics may be used to

513 evaluate whether the distributions of zircon $\varepsilon \mathrm{Hf}_{\mathrm{t}}$ and $\delta^{18} \mathrm{O}$ values are significantly different

514 between samples of the Ford Granodiorite suite, and between these and the granites and

515 diatexites. We use the nonparametric Kruskal-Wallis test (Kruskal and Wallis, 1952) that is

516 analogous to a parametric analysis of variances (ANOVA) test, except that it does not require

517 data that are normally distributed. 
The Ford Granodiorite suite samples divide into two groups. The two oldest members of

519 the suite (MB.214 and MB.219) have zircon with the most radiogenic $\varepsilon \mathrm{Hf}_{\mathrm{t}}$ and the lowest $\delta^{18} \mathrm{O}$

520 values, whereas the four younger samples have zircons with more evolved $\varepsilon \mathrm{Hf}_{\mathrm{t}}$ and higher $\delta^{18} \mathrm{O}$

521 values (Fig. 12). Based on results from the Kruskal-Wallis test (supplementary table DR10),

522 samples within each group are likely to have sampled the same population, whereas the two

523 groups of samples are likely to have sampled different populations. The $\varepsilon \mathrm{Hf}_{\mathrm{t}}$ and $\delta^{18} \mathrm{O}$ values for

524 the granites and diatexites are similar to the younger group of Ford Granodiorite suite samples

525 (Fig. 12, supplementary table DR10). These data suggest a change at ca. 370 Ma towards a larger

526 contribution from the Swanson Formation in the petrogenesis of the younger rocks. This change

527 is consistent with the study of Tulloch et al. (2009), who reported monazite ${ }^{207} \mathrm{~Pb} /{ }^{235} \mathrm{U}$ ages of ca.

$528359 \mathrm{Ma}$ and ca. $351 \mathrm{Ma}$ from muscovite-biotite granites from the Chester Mountains and

529 Neptune Nunataks (locations in Fig. 2), respectively, consistent with the postulated increasing

530 contribution from a sedimentary source after ca. $370 \mathrm{Ma}$.

\section{Potential source rocks}

533 Zircons from the Ford Granodiorite suite, the Devonian-Carboniferous granites and the 534 diatexites exhibit a range of $\delta^{18} \mathrm{O}$ and $\varepsilon \mathrm{Hf}_{\mathrm{t}}$ values. Many arc-related granitoids are thought to 535 represent a mixture of two or more source components (e.g. Kemp et al., 2009; Miles et al., 536 2014). The $\mathrm{Hf}$ and $\mathrm{O}$ isotope composition of zircon provides a potentially powerful tool to 537 evaluate the nature and proportional contribution of these source components to granitoid 538 petrogenesis (e.g. Kemp et al., 2007). These proportions may be evaluated if the isotope 539 composition of the source components is known and if they are sufficiently distinct from one 540 another. Hf isotopes may be used to distinguish between juvenile and ancient source 
541 components, whereas $\mathrm{O}$ isotopes may be used to determine if source components have been

542 subjected to surface processes, such as weathering and sedimentation, as indicated by high $\delta^{18} \mathrm{O}$

543 values (e.g. Hawkesworth and Kemp, 2006).

544 The majority of Hf in most crustal rocks is found in zircon. In a closed system, zircon

545 dissolution during partial melting will contribute Hf to the melt, which partitions into newly

546 formed zircon during melt crystallization. In this scenario, newly formed zircon is predicted to

547 have a similar Hf isotope composition to that of zircon in the protolith (e.g. Flowerdew et al.,

548 2006b). Although the breakdown of high Lu/Hf minerals such as apatite may also contribute

549 radiogenic Hf to the melt, the amount of $\mathrm{Hf}$ is expected to be relatively minor compared with Hf

550 contribution from the breakdown of zircon. Therefore, in a closed system, newly formed zircon

551 in a crystallized anatectic melt is predicted to have a similar Hf isotope composition to the

552 original magmatic grains in an igneous protolith, or to the detrital zircons in a metasedimentary

553 protolith, or to an intermediate composition where derived from a mixed source.

554 Oxygen isotope fractionation between zircon and granite magma will result in igneous

555 zircons that have slightly lower $\delta^{18} \mathrm{O}$ values (Valley et al., 1994; Valley 2003). By contrast, the

$556 \quad \delta^{18} \mathrm{O}$ composition measured in detrital zircon may not be representative of the whole-rock value

557 because oxygen is a major component in all of the major rock forming minerals, including those

558 that have formed at or near the surface. Therefore, granites derived by anatexis from sedimentary

559 protoliths may not have similar oxygen isotope compositions to detrital zircons in the source, but

560 they are expected have a composition similar to the whole rocks.

$561 \quad$ For the Ford Granodiorite suite, one potential source component is the regionally

562 distributed Swanson Formation. The $\varepsilon H f$ values of detrital zircons in the Swanson Formation,

563 recalculated to $360 \mathrm{Ma}$, vary from +2 to -67 , with a median value of -11.7 and an interquartile 
564 range of -3.5 to -19.9 (Figs. 10, 12 and 13). As discussed above, the $\delta^{18} \mathrm{O}$ value of zircons that 565 crystallized from melt produced from the Swanson Formation are expected to have values of $566 \sim 8.5-12 \%$, with a mean value of 10.5\%o (Figs. 10, 12 and 13). The Hf isotope composition of 567 zircons from the Ford Granodiorite suite reported in this study is more radiogenic than most 568 detrital zircons from the Swanson Formation (Fig. 10A). This suggests the involvement of a 569 source more juvenile than the Swanson Formation. The calc-alkaline chemistry of the Ford Granodiorite suite and its emplacement during a

571 period of widespread arc magmatism along the East Gondwanan plate margin suggests the 572 possible involvement of juvenile magma sourced from the arc mantle or a mafic underplate 573 derived from it. Such a source is inferred to have a $\delta^{18} \mathrm{O}$ value of $5.3 \pm 0.6 \%$ (Valley et al., 574 1998). The $\varepsilon \mathrm{Hf}$ of this source may range from that expected for new crust sourced from a slightly 575 enriched mantle wedge in an island arc (+12.2 at $360 \mathrm{Ma}$; Dhuime et al., 2011) to less radiogenic 576 values associated with a more enriched sub-continental lithospheric mantle above a subducting 577 slab. The $\varepsilon H f$ values for modified sub-continental lithospheric mantle may range from 0 (CHUR) 578 to +10 (Griffin et al., 2000). Therefore, for the purpose of petrogenetic modeling, two end579 member $\varepsilon H f$ values of 0 (CHUR) and +12.2 (new crust) have been chosen to represent the 580 juvenile source.

581 Excluding outliers (Fig. 12), data from the Ford Granodiorite suite reported in this study 582 have $\varepsilon \mathrm{Hf}_{\mathrm{t}}$ values that plot between those for the Swanson Formation and those for the juvenile 583 source (Fig. 10A). This suggests that a petrogenetic scenario similar to the model developed for 584 granites in the Lachlan Fold Belt of the Tasmanides orogen may be applicable to the Ford 585 Granodiorite suite. The Lachlan granites were interpreted to be the mixed products of 586 sedimentary material reworked by juvenile magma in the deep crust (Kemp et al., 2007). 
587 Accordingly, binary mixing curves between Swanson Formation and mantle have been

588 calculated to evaluate this model for the petrogenesis of the Ford Granodiorite suite (Fig. 13A).

589 Four scenarios are modeled: two where different juvenile magma compositions, discussed above,

590 are mixed with Swanson Formation en masse and two where these same juvenile magma

591 compositions are mixed with anatectic melt derived from the Swanson Formation.

592 The curvature of the mixing lines is most sensitive to the relative concentrations of Hf in

593 each of the end-members. There are no data available for mafic rocks of an appropriate age in

594 Marie Byrd Land. Therefore, for the juvenile source, an Hf concentration of 2.3 ppm is used,

595 which is a representative composition for mafic rocks temporally associated with Devonian

596 granites in the Lachlan Fold Belt of the Tasmanides orogen (e.g. Kemp et al., 2007). For the

597 Swanson Formation, an average whole-rock concentration of $3.2 \mathrm{ppm}$ was assigned based on

598 bulk chemical analyses (Korhonen et al., 2010a). For melt derived from the Swanson Formation,

599 a concentration of $1.0 \mathrm{ppm}$ is used, which represents the average Hf concentration of deep crustal

600 granites that were interpreted to be derived predominantly from a Swanson Formation source

601 inside the Fosdick complex (Korhonen et al., 2010a).

602 For the four younger Ford Granodiorite suite samples analyzed in this study, a large

603 proportion of the Hf and $\mathrm{O}$ isotope compositions of the zircons may be explained by this model,

604 particularly for mixing magma from the juvenile source with anatectic melt from the Swanson

605 Formation. This is consistent with rare zircon cores within some samples that correspond to the

606 main age populations found in the Swanson Formation and paragneiss detrital zircons (Fig. 3).

607 Mixing between juvenile magma and 40-80\% anatectic melt derived from the Swanson

608 Formation is required to explain the range of measured values for the Ford Granodiorite suite

609 samples (Fig. 13A). 
An alternative scenario that cannot be ruled out by the data is one in which the earliest

611 members of the Ford Granodiorite suite are reworked in the deep crust, generating melts that mix

612 with those derived from the Swanson Formation or assimilate Swanson Formation en masse to

613 produce the younger members of the Ford Granodiorite suite. To explore this scenario the data

614 from this study are combined with data from Yakymchuk et al. (2013a). These data are plotted as

615 two fields in Figure 13B, one for two older members of the Ford Granodiorite suite (samples

616 MB.214 and MB.219) and a second for the four younger members of the Ford Granodiorite suite

617 shown in Figure 13A. Most of the Hf and O isotope compositions of zircons from the younger

618 members of the Ford Granodiorite suite may be explained by mixing of anatectic melt from older

619 members of the suite with anatectic melt from the Swanson Formation (Fig. 13B). This is

620 consistent with the small population of slightly older zircon dates from sample Y2-JU096 that

621 yielded an age of ca. $377 \mathrm{Ma}$ (Fig. 5). However, the Hf and O isotope composition of zircons

622 from samples MB.214 and MB.219 also lie inside the curves for juvenile magma mixing with

623 melts derived from the Swanson Formation or for assimilation of Swanson Formation en masse

624 (compare the fields in Fig. 13B with the model mixing curves in Fig. 13A). Thus, any

625 contribution to the petrogenesis of the younger members of the Ford Granodiorite suite derived 626 by reworking of these older compositions would have been masked by any ongoing input from 627 the juvenile mantle source, and the two alternative scenarios cannot be distinguished.

\section{The granites and diatexites}

630 The granites and diatexites generally have whole-rock $\mathrm{Sr}$ and $\mathrm{Nd}$, and zircon $\mathrm{Hf}$ and $\mathrm{O}$

631 isotope compositions that lie between those of the most primitive Ford Granodiorite suite 
632 members and the least evolved Swanson Formation (Figs. 6 and 13). This observation permits a

633 variety of plausible scenarios for the petrogenesis of the granites and diatexites.

634 The first possibility is that juvenile magma could have assimilated Swanson Formation en 635 masse or mixed with anatectic melt derived from the Swanson Formation in a fashion similar to 636 the model proposed for the petrogenesis of the Ford Granodiorite suite (compare the data in Fig.

$63713 \mathrm{C}$ with the model mixing curves in Fig. 13A). However, this option considered the least likely

638 based on the variable oxide and trace element distributions of the granites and diatexites

639 compared with the more regular distributions shown by the Ford Granodiorite suite samples (Fig.

640 6) and the differences in REE patterns (Fig. 7).

Four alternative possibilities are: (1) Ford Granodiorite suite magmas could have mixed

642 with anatectic melt derived from the Swanson Formation, (2) Ford Granodiorite suite magmas

643 could have assimilated Swanson Formation en masse, (3) melt derived from early-crystallized

644 members of the Ford Granodiorite suite by anatexis could have mixed with anatectic melt

645 derived from the Swanson Formation, and (4) melt derived from early-crystallized members of

646 the Ford Granodiorite suite by anatexis could have assimilated Swanson Formation en masse, as

647 proposed by Korhonen et al. (2010a).

648 First, we evaluate these four options using the $\mathrm{Sr}$ and $\mathrm{Nd}$ isotope compositions

649 recalculated to 360 Ma. Figure 8 shows binary mixing lines that connect representative

650 compositions of the Swanson Formation and the Ford Granodiorite suite calculated using the $\mathrm{Sr}$

651 and $\mathrm{Nd}$ concentrations and isotope values of more and less radiogenic end-member samples (Fig.

652 8). With the exception of granite sample C5-Is51a (reported by Korhonen et al., 2010a) and the

653 inhomogeneous diatexite (Y1-IG071), the granites plot between the two sources but closer to the

654 Ford Granodiorite suite. The $\mathrm{Sr}$ and $\mathrm{Nd}$ isotope values of the granites and the homogeneous 
655 diatexite allow a contribution of up to 30 vol.\% Swanson Formation (Fig. 8). The

656 inhomogeneous diatexite (Y1-IG071) plots at less radiogenic $\varepsilon N d$ values than the Ford

657 Granodiorite suite but also at lower ${ }^{87} \mathrm{Sr}^{86} \mathrm{Sr}_{360}$ values than the Swanson Formation (Fig. 8). This

658 sample contains a significant population of $100 \mathrm{Ma}$ zircons. If the $\mathrm{Sr}$ and $\mathrm{Nd}$ isotope ratios are

659 recalculated to $100 \mathrm{Ma}$, the inhomogeneous diatexite falls between the $\varepsilon \mathrm{Nd}$ and ${ }^{87} \mathrm{Sr} /{ }^{86} \mathrm{Sr}_{100}$

660 values of two putative sources, which is interpreted to indicate that this sample records the

661 effects of the Cretaceous overprint in the Fosdick complex.

662 Second, we use the zircon Hf and O isotope compositions. Figure 13C shows binary

663 mixing lines that connect representative compositions of the Swanson Formation and the Ford

664 Granodiorite suite. These were calculated using Hf concentrations of 3.3 ppm for the Ford

665 Granodiorite suite magmas and $1.0 \mathrm{ppm}$ for anatectic melts derived from early members of the

666 Ford Granodiorite suite combined with the Hf concentrations discussed above for the Swanson

667 Formation. Note that assimilation of Swanson Formation en masse by Ford Granodiorite suite

668 magma and mixing of anatectic melts derived from early members of the Ford Granodiorite suite

669 with those derived from the Swanson Formation yield similar binary mixing curves that cannot

670 be distinguished in Figure 13C. The modeling permits by all four petrogenetic scenarios

671 discussed above; in almost all cases the proportion of Ford Granodiorite suite component

672 required by the data is greater than the Swanson Formation component.

673 To further test these two alternatives, the major-element compositional variability of

674 Devonian-Carboniferous granites and diatexites is investigated using the ternary system

675 (Na+Ca) $-\left(\mathrm{Fe}^{*}+\mathrm{Mg}+\mathrm{Ti}\right)-\mathrm{K}$ (Solar and Brown, 2001). Because there have been no melting

676 experiments done on the either the Ford Granodiorite suite or the Swanson Formation,

677 experimental melt compositions from Skjerlie et al. (1993) and Patiño Douce and Harris (1998) 
678 were used based on similarity in chemical composition of the experimental starting materials to

679 the putative sources of the granites. The experimental melts from Skjerlie et al. (1993) were used

680 as proxies for melts derived from the Ford Granodiorite suite while the experimental results of

681 Patiño Douce and Harris (1998) were used to infer melt compositions derived from the Swanson

682 Formation. The compositions of the starting materials and melts are plotted along with samples

683 from the Swanson Formation, Ford Granodiorite suite, and the granites and diatexites in Figure

684 14. There is a wide range of possible granite and diatexite compositions that may be achieved by

685 assimilation or mixing between Ford Granodiorite suite compositions, Swanson Formation

686 compositions and melts derived from each, as shown by the shaded areas in Figure 14,

687 particularly given the propensity of crustal melts to entrain peritectic residue (Clemens et al.,

688 2011; Clemens and Stevens, 2012). As a result, the four alternative petrogenetic scenarios

689 considered — that Ford Granodiorite suite magmas or melts derived from early-crystallized

690 members of the suite could have assimilated Swanson Formation en masse or mixed with

691 anatectic melt derived from the Swanson Formation — cannot be discriminated.

692

693 WIDER CONSIDERATIONS

694 Implications for a Proterozoic basement

695 An outstanding question in western Marie Byrd Land is the nature and age of the

696 basement to the Swanson Formation. Evidence supporting a Proterozoic basement includes: (1)

697 inherited zircons in granites that yield Proterozoic ages (Fig. 3G) or Proterozoic concordia upper

698 intercept ages (Pankhurst et al., 1998; Mukasa and Dalziel, 2000); (2) Proterozoic Nd model ages

699 for the Ford Granodiorite suite (Pankhurst et al., 1998); and (3) Proterozoic Os isotope model

700 ages for peridotite xenoliths from the upper mantle beneath Eastern Marie Byrd Land, which 
701 assumes that the crust and underlying mantle are temporally coupled (Handler et al., 2003).

702 However, aeromagnetic anomalies north Victoria Land led Finn et al. (1999) to suggest that

703 sedimentary rocks that make up the Robertson Bay Terrane-proposed to be correlative with the

704 Swanson Formation in Marie Byrd Land-were deposited on forearc oceanic crust. The

705 geological and geochemical evidence for the age of the basement to the Swanson Formation is

706 evaluated below.

707 Granites from Marie Byrd Land commonly contain zircons with xenocrystic cores that

708 may reflect inheritance from a Precambrian source (e.g. Mukasa and Dalziel, 2000), or

709 alternatively, these grains may represent detrital zircons scavenged from sedimentary rocks

710 during formation and/or emplacement. In the Ford Granodiorite suite, Devonian-Carboniferous

711 granites and diatexites, inherited zircon grains yield dates of 2277 to $412 \mathrm{Ma}$ and define a

712 dominant Neoproterozoic-Cambrian population (Fig. 3G). The similarity of this age population

713 to the Neoproterozoic-Cambrian age population in the Swanson Formation suggests the

714 possibility of scavenged detrital zircon grains, which is supported by the requirement for a

715 Swanson Formation component in the petrogenesis of the Ford Granodiorite suite, Devonian-

716 Carboniferous granites and diatexites. Therefore, these inherited grains do not provide direct

717 evidence of a Precambrian basement beneath western Marie Byrd Land.

718 The Ford Granodiorite suite yields Proterozoic Nd model ages that have been interpreted

719 to reflect a Proterozoic basement in western Marie Byrd Land (Pankhurst et al., 1998). However,

720 the Ford Granodiorite suite represents a mixture of juvenile (mantle-derived) and

721 metasedimentary components, as demonstrated by the elevated $\delta^{18} \mathrm{O}$ values of the zircons (Fig.

722 10). Therefore, the Nd model ages likely represent hybrids resulting from a mixture of two

723 components and they may not reflect the true age of the basement. 
Handler et al. (2003) document Mesoproterozoic Os model ages from mantle xenoliths in

725 Cenozoic volcanic rocks from the Executive Committee Range in Marie Byrd Land, which is

$726 \sim 500 \mathrm{~km}$ away from the Ford Ranges. The partial melting and subsequent stabilization of mantle

727 lithosphere at this time likely resulted in additions of juvenile magma to the crust, which

728 potentially could represent a nearby source for Mesoproterozoic detrital zircons with juvenile

$729 \varepsilon \mathrm{Hf}_{\mathrm{t}}$ values similar to those in the Swanson Formation. However, given the distance between the

730 Ford Ranges and the Executive Committee Range, it is not required that the Swanson Formation

731 was deposited on this Proterozoic basement.

732 An alternative model is that the Swanson Formation was deposited on a Paleozoic

733 oceanic basement, as has been proposed for the Robertson Bay Terrane in north Victoria Land

734 (Finn et al., 1999) and for the Lachlan Fold Belt of the Tasmanides orogen (Foster et al., 2009).

735 A positive test of this hypothesis would be the retrieval of Paleozoic Os model ages from mantle

736 xenoliths that occur in Cenozoic volcanic rocks in the Ford Ranges.

\section{Correlation along the Gondwana margin}

739 The former continental margin of Gondwana represents one of the most extensive and

740 long-lived active convergent plate margins in the Phanerozoic and is the type example of an

741 external (circum-Pacific) orogenic system (Cawood, 2005; Collins et al., 2011). Parts of the

742 landmasses of Australia and New Zealand (Zealandia) were situated along the active margin of

743 Gondwana together with north Victoria Land and Marie Byrd Land from the Paleozoic through

744 the final breakup of Gondwana in the Cretaceous (Fig. 1B). The ages and isotope values of

745 granites from different segments along the Gondwanan margin can provide insight into the

746 similarities and differences in the processes operating along an active continental margin (e.g. 
747 Yakymchuk et al., 2013a). However, such a comparison is limited by the paucity of zircon Hf

748 isotope data from granites in New Zealand and north Victoria Land. Therefore, in this section we

749 use both whole-rock $\mathrm{Nd}$ and zircon $\mathrm{Hf}$ isotope data from granites in each of these locations, as

750 shown in Figure 15.

751 In eastern Australia, the Tasmanides orogen is attributed to alternating extensional and

752 contractional tectonics associated with a west-dipping subduction zone that migrated oceanward

753 from the Cambrian to the Permian (e.g. Collins, 2002; Glen, 2005; Cawood, 2005). A protracted

754 period of Silurian to Devonian silicic magmatism is recorded in the Tasmanides with minor

755 Carboniferous magmatism. These granites record a progression towards more radiogenic whole-

756 rock $\varepsilon N d$ and zircon $\varepsilon \mathrm{Hf}_{\mathrm{t}}$ values with time (Fig. 15A, B), which has been tied to crustal growth

757 accompanying slab rollback and back-arc rifting after crustal thickening (Kemp et al., 2009).

758 Granites from the Western Province of New Zealand show a similar trend, although at a later

759 time than the granites from the Tasmanides (Fig. 15A). In contrast, the Ford Granodiorite suite

760 and its correlatives in north Victoria Land were emplaced over relatively short periods in the

761 Devonian-Carboniferous and do not show the same temporal trends (Fig. 15A, B).

762 In north Victoria Land, correlative Devonian-Carboniferous igneous rocks include the

763 Admiralty Intrusives (371-351 Ma; Borg et al., 1987; Fioretti et al. 1997; Henjes-Kunst and

764 Kreuzer, 2003), the Salamander Granite complex (ca. 347 Ma; Henjes-Kunst and Kreuzer,

765 2003), and associated volcanic rocks (369-357 Ma; Henjes-Kunst and Kreuzer 2003). Although

766 there is only limited $\mathrm{Nd}$ isotope data from the Admiralty Intrusives in north Victoria Land (Borg

767 et al., 1986), they have a similar range of $\varepsilon \mathrm{Nd}$ values to those from the Ford Granodiorite suite

768 (Fig. 15A). The ages of these rocks were constrained by Rb-Sr isochrons to the range 393-364

769 Ma and, thus, generally older than the Ford Granodiorite suite. However, Henjes-Kunst and 
770 Kreuzer (2003) report Ar-Ar biotite ages and one U-Pb zircon age from other Admiralty

771 Intrusive rocks in the range 371-354 Ma, which casts some doubt about the veracity of the $\mathrm{Rb}-$

772 Sr ages. Assuming contemporaneity between the Ford Granodiorite suite and the Admiralty

773 Intrusives, the $\mathrm{Nd}$ isotope data suggest both were derived from an isotopically similar source.

774 In the Western Province of New Zealand, Devonian-Carboniferous igneous rocks coeval

775 with the Ford Granodiorite suite include the Karamea-Paringa suite (371-351 Ma; Tulloch et al,

776 2009; Sagar and Palin, 2013) and the Ridge-Tobin suite (355-342 Ma; Tulloch et al, 2009).

777 Granites from the volumetrically dominant Karamea suite have $\varepsilon N d$ values of -3 to -9 and

778 estimated magma $\delta^{18} \mathrm{O}$ values of 10.8 to $12.5 \%$ (Tulloch et al., 2009), which indicates that these

779 granites were derived primarily from a metasedimentary source. Younger granite suites from the

780 Western Province generally have more radiogenic $\varepsilon \mathrm{Nd}$ and $\varepsilon \mathrm{Hf}_{\mathrm{t}}$ zircon values (Fig. 15A, B) and

781 more mantle-like $\delta^{18} \mathrm{O}$ values than the Ford Granodiorite suite. In the Western Province, the high

$782 \delta^{18} \mathrm{O}$ values of the Karamea suite granites, their rapid emplacement (370-368 Ma; Tulloch et al.,

783 2009), occurrence of contemporaneous mafic rocks (Turnbull et al., 2013), and partial melting at

784 low pressures $\left(\sim 670^{\circ} \mathrm{C}\right.$ at $0.5 \mathrm{GPa}$; Scott et al., 2011) may indicate a period of lithospheric

785 extension and asthenospheric upwelling. Scott et al. (2011) suggest that crustal thinning may

786 have been related to slab rollback or subduction cessation along this portion of the Gondwana

787 margin. The lack of similar trends towards more radiogenic $\varepsilon N d$ values over time in Devonian-

788 Carboniferous granites in western Marie Byrd Land and north Victoria Land (Fig. 15A) and the

789 paucity of associated mafic rocks does not support a period of back-arc extension in these

790 regions at this time. Therefore, the effects of slab rollback and lithospheric extension may be

791 confined to the Western Province of New Zealand, which may have occupied a position closer to

792 the subduction trench in the Devonian-Carboniferous (Veevers, 2012). 
Overall, the changes in isotope composition and source characteristics recorded by arc-

794 related granitoids from eastern Australia to north Victoria Land to the Western Province of New

795 Zealand and Marie Byrd Land may relate to an along-arc change from the typical extensional

796 accretionary mode in eastern Australia to a neutral or an advancing mode in West Antarctica, and

797 to an across-arc difference in distance from the trench between the New Zealand fragments of

798 Zealandia and western Marie Byrd Land.

\section{CONCLUSIONS}

801 In the Ford Ranges of Marie Byrd Land, new U-Pb ages and Hf-isotope compositions of

802 detrital zircons from the Swanson Formation and equivalent metasedimentary rocks combined

803 with published data reveals three principal age populations. The largest population comprises

804 Neoproterozoic-Cambrian zircons with evolved Hf isotope values consistent with derivation

805 from reworked Mesoproterozoic crust. These zircons were likely sourced from a region of

806 igneous and metamorphic rocks associated with the Ross-Delamerian Orogen that now lies

807 beneath the East Antarctic ice sheet. A second population of Mesoproterozoic detrital zircons

808 with juvenile Hf isotope values is consistent with derivation from crust, or sedimentary

809 derivatives of crust, similar to the gneiss that crops out in the Haag Nunataks and a granite clast

810 that originated from a Mesoproterozoic orogenic belt located beneath the Antarctic ice sheet. A

811 third population of Paleoproterozoic zircons could have been sourced from Precambrian

812 basement exposed in the central Transantarctic Mountains. Detrital zircon age distributions and

813 Hf isotope measurements from the (meta-) sedimentary rocks document a major crust-forming

814 event in the Mesoproterozoic during the transition from Nuna (Columbia) to Rodinia and

815 extensive crustal reworking during Ross-Delamerian orogenesis. 
817 diatexites define a short-lived period of magmatism in the Ford Ranges from 375 to 345 Ma. The

818 Hf and $\mathrm{O}$ isotope compositions of zircons from the oldest Ford Granodiorite suite samples are

819 consistent with mixing of a juvenile magma with Swanson Formation in an active arc setting.

820 Isotope values of zircons from the younger members of the Ford Granodiorite suite are also

821 compatible with this petrogenetic scenario but require a larger proportion of Swanson Formation.

822 Alternatively, these younger members may have been derived by anatectic reworking of older

823 members of the Ford Granodiorite suite and mixing with Swanson Formation either en masse or

824 as melts in the deep crust. The Devonian-Carboniferous granites and diatexites from the Fosdick

825 complex represent Ford Granodiorite suite magmas or anatectic melt derived from early-

826 crystallized members of the suite that assimilated Swanson Formation en masse or mixed with

827 anatectic melt derived from the Swanson Formation. The Ford Granodiorite suite and the

828 granites and diatexites do not show the same temporal trends in source compositions recorded by

829 similar-age circum-Pacific granite suites in Eastern Australia, north Victoria Land and the

830 Western Province of New Zealand.

\section{ACKNOWLEDGEMENTS}

833 This work was supported by the National Science Foundation under Grant No. ANT0944615 to

$834 \mathrm{MB}$ at the University of Maryland, and Grant Nos OPP-0338279 and OPP-0944600 to CS at

835 Colorado College. The authors acknowledge used of facilities in the NanoCenter and the NISP-

836 Lab at the University of Maryland, which are supported as a MRSEC Shared Experimental

837 Facility. CY was partially funded by a post-graduate scholarship from the National Science and

838 Engineering Research Council of Canada. We thank T. Burton, K. Emery and D. Uhlmann for 
their contribution to field logistics and safety, and Kenn Borek Air and Raytheon Polar Services

personnel for transportation and logistical support. We thank M. Pecha and N. Giesler for

thorough and constructive reviews, and C. Miller for editorial comments and advice.

846

\section{REFERENCES}

Adams, C. J. 1986. Geochronological studies of the Swanson Formation of Marie Byrd Land, West Antarctica, and correlation with northern Victoria Land, East Antarctica and the South Island, New Zealand. New Zealand Journal of Geology and Geophysics, v. 29, p. 345-358. doi: 10.1080/00288306.1986.10422157.

Adams, C. J., 1987, Geochronology of granite terranes in the Ford Ranges, Marie Byrd Land, West Antarctica: New Zealand Journal of Geology and Geophysics, v. 30, p. 51-72. doi:10.1080/00288306.1987.10422193.

Adams, C. J., 2004, Rb-Sr age and strontium isotope characteristics of the Greenland Group, Buller Terrane, New Zealand, and correlations at the east Gondwanaland margin: New Zealand Journal of Geology and Geophysics, v. 47, p. 189-200. doi:10.1080/00288306.2004.9515047.

Adams, C. J., 2010, Lost Terranes of Zealandia: possible development of late Paleozoic and early Mesozoic sedimentary basins at the southwest Pacific margin of Gondwana: Andean Geology, v. 37, p. 442-454. doi:10.5027/andgeoV37n2-a10.

Adams, C. J., Pankhurst, R. J., Maas, R., and Millar, I. L., 2005, Nd and Sr isotopic signatures of metasedimentary rocks around the South Pacific margin and implications for their provenance: Geological Society, London, Special Publications, v. 246, no. 1, p. 113-141. doi: 10.1144/GSL.SP.2005.246.01.04.

Adams, C. J., Mortimer, N., Campbell, H. J., and Griffin, W. L., 2013, The mid-Cretaceous transition from basement to cover within sedimentary rocks in eastern New Zealand; evidence from detrital zircon age patterns: Geological Magazine, v. 150, p. 455-478. doi:10.1017/s0016756812000611.

Allibone, A., and Wysoczanski, R., 2002, Initiation of magmatism during the CambrianOrdovician Ross Orogeny in southern Victoria Land, Antarctica: Geological Society of America Bulletin, v. 114, p. 1007-1018. doi:10.1130/00167606(2002)114<1007:iomdtc $>2.0 . c 0 ; 2$.

Bolhar, R., Weaver, S. D., Whitehouse, M. J., Palin, J. M., Woodhead, J. D., and Cole, J. W., 2008, Sources and evolution of arc magmas inferred from coupled $\mathrm{O}$ and $\mathrm{Hf}$ isotope systematics of plutonic zircons from the Cretaceous Separation Point Suite (New 
878

879

880

881

882

883

884

885

886

887

888

889

890

891

892

893

894

895

896

897

898

899

900

901

902

903

904

905

906

907

908

909

910

911

912

913

914

915

916

917

918

919

920

921

922
Zealand): Earth and Planetary Science Letters, v. 268, p. 312-324.

doi:10.1016/j.eps1.2008.01.022.

Bomparola, R. M., Ghezzo, C., Belousova, E., Griffin, W. L., and O'Reilly, S. Y., 2007, Resetting of the U-Pb Zircon System in Cambro-Ordovician Intrusives of the Deep Freeze Range, Northern Victoria Land, Antarctica: Journal of Petrology, v. 48, p. $327-$ 364. doi:10.1093/petrology/eg1064.

Borg, S. G., and DePaolo, D. J., 1991, A tectonic model of the Antarctic Gondwana margin with implications for southeastern Australia: isotopic and geochemical evidence: Tectonophysics, v. 196, p. 339-358. doi:10.1016/0040-1951(91)90329-Q.

Borg, S., Stump, E., and Holloway, J., 1986, Granitoids of northern Victoria Land, Antarctica: A reconnaissance study of field relations, petrography, and geochemistry: Antarctic Research Series, v. 46, p. 115-188.

Borg, S. G., Stump, E., Chappell, B. W., McCulloch, M. T., Wyborn, D., Armstrong, R. L., and Holloway, J. R., 1987, Granitoids of northern Victoria Land, Antarctica; implications of chemical and isotopic variations to regional crustal structure and tectonics: American Journal of Science, v. 287, p. 127-169. doi:10.2475/ajs.287.2.127.

Bradshaw, J. D., Andrews, P. B., and Field, B. D., 1983, Swanson Formation and related rocks of Marie Byrd Land and a comparison with the Robertson Bay Group of northern Victoria Land in Oliver, R.K., James, P.R., and Jago, J.B. (Eds). Antarctic Earth Science. Cambridge University Press: Cambridge, United Kingdom, p. 274-279.

Bradshaw, J. D., Vaughan, A. P., Millar, I. L., Flowerdew, M. J., Trouw, R. A., Fanning, C., and Whitehouse, M. J., 2012, Permo-Carboniferous conglomerates in the Trinity Peninsula Group at View Point, Antarctic Peninsula: sedimentology, geochronology and isotope evidence for provenance and tectonic setting in Gondwana: Geological Magazine, v. 149, p. 626-644. doi:10.1017/S001675681100080X.

Brown, M., 1973. The Definition of Metatexis, Diatexis and Migmatite. Proceedings of the Geologists' Association, 84, 371-382. doi:10.1016/S0016-7878(73)80021-5

Cawood, P. A., 2005, Terra Australis Orogen: Rodinia breakup and development of the Pacific and Iapetus margins of Gondwana during the Neoproterozoic and Paleozoic: EarthScience Reviews, v. 69, p. 249-279. doi:10.1016/j.earscirev.2004.09.001.

Cecil, M. R., Gehrels, G. E., Ducea, M. N., and Patchett, P. J., 2011, U-Pb-Hf characterization of the central Coast Mountains Batholith; implications for petrogenesis and crustal architecture: Lithosphere, v. 3, p. 247-260. doi:10.1130/1134.1.

Chappell, B. W., White, A. J. R., and Hine, R., 1988, Granite provinces and basement terranes in the Lachlan Fold Belt, southeastern Australia: Australian Journal of Earth Sciences, v. 35, p. 505-521. doi:10.1080/08120098808729466.

Clemens, J.D., and Stevens, G., 2012, What controls chemical variation in granitic magmas?: Lithos, v. 134-135, p. 317-329, doi:10.1016/j.lithos.2012.01.001.

Clemens, J.D., Stevens, G., and Farina, F., 2011, The enigmatic sources of I-type granites: The peritectic connexion: Lithos, v. 126, p. 174-181, doi:10.1016/j.lithos.2011.07.004.

Collins, W. J., 2002, Nature of extensional accretionary orogens: Tectonics, v. 21, p. 6-1-6-12. doi:10.1029/2000tc001272.

Collins, W. J., Belousova, E. A., Kemp, A. I. S., and Murphy, J. B., 2011, Two contrasting Phanerozoic orogenic systems revealed by hafnium isotope data: Nature Geosci, v. 4, p. 333-337. doi:10.1038/ngeo1127. 
923

924

925

926

927

928

929

930

931

932

933

934

935

936

937

938

939

940

941

942

943

944

945

946

947

948

949

950

951

952

953

954

955

956

957

958

959

960

961

962

963

964

965

966

967
Dallai, L., Ghezzo, C., and Sharp, Z. D., 2003, Oxygen isotope evidence for crustal assimilation and magma mixing in the Granite Harbour Intrusives, northern Victoria Land, Antarctica: Lithos, v. 67, p. 135-151. doi:10.1016/S0024-4937(02)00267-0.

DePaolo, D. J., 1981, Trace element and isotopic effects of combined wallrock assimilation and fractional crystallization: Earth and Planetary Science Letters, v. 53, p. 189-202. doi:10.1016/0012-821X(81)90153-9.

DiVenere, V. J., Kent, D. V., and Dalziel, I. W. D., 1994, Mid-Cretaceous paleomagnetic results from Marie Byrd Land, West Antarctica; a test of post-100 Ma relative motion between East and West Antarctica: Journal of Geophysical Research, v. 99, p. 15115-15139. doi:10.1029/94jb00807.

DiVenere, V., Kent, D. V., and Dalziel, I. W. D., 1995, Early Cretaceous paleomagnetic results from Marie Byrd Land, West Antarctica: Implications for the Weddellia collage of crustal blocks: Journal of Geophysical Research: Solid Earth, v. 100, p. 8133-8151. doi:10.1029/95jb00042.

Di Vincenzo, G., Grande, A., and Rossetti, F., 2014, Paleozoic siliciclastic rocks from northern Victoria Land (Antarctica): Provenance, timing of deformation, and implications for the Antarctica-Australia connection: Geological Society of America Bulletin, doi:10.1130/b31034.1.

Dhuime, B., Hawkesworth, C., and Cawood, P., 2011, When Continents Formed: Science, v. 331, p. 154-155. doi:10.1126/science.1201245.

Elliot, D. H., Fanning, C. M., and Hulett, S. R. W., 2014, Age provinces in the Antarctic craton: Evidence from detrital zircons in Permian strata from the Beardmore Glacier region, Antarctica: Gondwana Research. doi: 10.1016/j.gr.2014.03.013.

Finn, C., Moore, D., Damaske, D., and Mackey, T., 1999, Aeromagnetic legacy of early Paleozoic subduction along the Pacific margin of Gondwana: Geology, v. 27, p. 1087 1090. doi:10.1130/0091-7613(1999)027<1087:aloeps>2.3.co;2.

Fioretti, A. M., Visona, D., Cavazzini, G., and Lombardo, B., 1997, Devonian magmatism; implications for the evolution of northern Victoria Land, Antarctica, and correlation with southeastern Australia and northeastern Tasmania: International Symposium on Antarctic Earth Sciences, v. 7, p. 293-296.

Flowerdew, M. J., Millar, I. L., Curtis, M. L., Vaughan, A. P. M., Horstwood, M. S. A., Whitehouse, M. J., and Fanning, C. M., 2007, Combined U-Pb geochronology and Hf isotope geochemistry of detrital zircons from early Paleozoic sedimentary rocks, Ellsworth-Whitmore Mountains Block, Antarctica: Geological Society of America Bulletin, v. 119, p. 275-288. doi:10.1130/b25891.1.

Flowerdew, M. J., Millar, I. L., and Vaughan, A. P. M., 2006a, Potential of Combined U-Pb Geochronology and Hf isotope Geochemical Studies on Zircon to Aid Sedimentary Provenance within Antarctica: Examples from West Antarctica: Terra Antarctica Reports, v. 12 , p. 57-64.

Flowerdew, M., Millar, I., Vaughan, A., Horstwood, M., and Fanning, C., 2006b, The source of granitic gneisses and migmatites in the Antarctic Peninsula: a combined U-Pb SHRIMP and laser ablation Hf isotope study of complex zircons: Contributions to Mineralogy and Petrology, v. 151, no. 6, p. 751-768. doi: 10.1007/s00410-006-0091-6.

Foster, D. A., Gray, D. R., Spaggiari, C., Kamenov, G., and Bierlein, F. P., 2009, Palaeozoic Lachlan orogen, Australia; accretion and construction of continental crust in a marginal 
1001

1002

1003

1004

1005

1006

1007

1008

1009

1010

1011

ocean setting: isotopic evidence from Cambrian metavolcanic rocks: Geological Society, London, Special Publications, v. 318, p. 329-349. doi:10.1144/sp318.12.

Gehrels, G. E., Valencia, V. A., and Ruiz, J., 2008, Enhanced precision, accuracy, efficiency, and spatial resolution of $\mathrm{U}-\mathrm{Pb}$ ages by laser ablation-multicollector-inductively coupled plasma-mass spectrometry: Geochemistry, Geophysics, Geosystems, v. 9, p. Q03017. doi: $10.1029 / 2007 \mathrm{gc001805.}$

Glen, R. A., 2005, The Tasmanides of eastern Australia: Geological Society, London, Special Publications, v. 246, p. 23-96. doi:10.1144/gsl.sp.2005.246.01.02.

Glen, R. A., Saeed, A., Quinn, C. D., and Griffin, W. L., 2011, U-Pb and Hf isotope data from zircons in the Macquarie Arc, Lachlan Orogen: Implications for arc evolution and Ordovician palaeogeography along part of the east Gondwana margin: Gondwana Research, v. 19, p. 670-685. doi:10.1016/j.gr.2010.11.011.

Goodge, J., and Fanning, C., 2002, Precambrian crustal history of the Nimrod Group, central Transantarctic Mountains, in Proceedings Antarctica at the Close of a Millennium, Proceedings of the 8th International Symposium on Antarctic Earth Science. Royal Society of New Zealand Bulletin, Volume 35, p. 43-50.

Goodge, J. W., and Finn, C. A., 2010, Glimpses of East Antarctica: Aeromagnetic and satellite magnetic view from the central Transantarctic Mountains of East Antarctica: Journal of Geophysical Research: Solid Earth, v. 115, p. B09103. doi:10.1029/2009jb006890.

Goodge, J. W., Fanning, C. M., and Bennett, V. C., 2001, U-Pb evidence of $\sim 1.7$ Ga crustal tectonism during the Nimrod Orogeny in the Transantarctic Mountains, Antarctica: implications for Proterozoic plate reconstructions: Precambrian Research, v. 112, p. 261 288. doi:10.1016/S0301-9268(01)00193-0.

Goodge, J. W., Fanning, C. M., Devon, M. B., Licht, K. J., and Emerson, F. P., 2010, Continuation of the Laurentian Grenville Province across the Ross Sea Margin of East Antarctica: The Journal of Geology, v. 118, p. 601-619. doi:10.1086/656385.

Goodge, J. W., Fanning, C. M., Norman, M. D., and Bennett, V. C., 2012, Temporal, Isotopic and Spatial Relations of Early Paleozoic Gondwana-Margin Arc Magmatism, Central Transantarctic Mountains, Antarctica: Journal of Petrology, v. 53, p. 2027-2065. doi:10.1093/petrology/egs043.

Goodge, J. W., Fanning, C. M., Vervoort J.D., and Fisher, C.M. 2013. Archean, Paleoproterozoic and Mesoproterozoic crust of Cetntral East Anrarctica: New insights on subglacial geology strengthen Rodinia ties to Western Laurentia. In Geological Society of America Abstracts with Programs, v. 45, No. 7.

Griffin, W. L., Pearson, N. J., Belousova, E., Jackson, S E, van Achterbergh, E , O, Reilly, S Y., and Shee, S. R., 2000, The Hf isotope composition of cratonic mantle: LAM-MCICPMS analysis of zircon megacrysts in kimberlites: Geochimica et Cosmochimica Acta, v. 64, p. 133-147. doi:10.1016/S0016-7037(99)00343-9.

Handler, M. R., Wysoczanski, R. J., and Gamble, J. A., 2003, Proterozoic lithosphere in Marie Byrd Land, West Antarctica; Re-Os systematics of spinel peridotite xenoliths: Chemical geology, v. 196, p. 131-145. doi:10.1016/s0009-2541(02)00410-2.

Harley, S. L., Fitzsimons, I. C. W., and Zhao, Y., 2013, Antarctica and supercontinent evolution: historical perspectives, recent advances and unresolved issues: Geological Society, London, Special Publications, v. 383, p. 1-34. doi:10.1144/SP383.9. 
1012

1013

1014

1015

1016

1017

1018

1019

1020

1021

1022

1023

1024

1025

1026

1027

1028

1029

1030

1031

1032

1033

1034

1035

1036

1037

1038

1039

1040

1041

1042

1043

1044

1045

1046

1047

1048

1049

1050

1051

1052

1053

1054

1055

1056
Hawkesworth, C. J., and Kemp, A. I. S., 2006, Using hafnium and oxygen isotopes in zircons to unravel the record of crustal evolution: Chemical geology, v. 226, p. 144-162. doi:10.1016/j.chemgeo.2005.09.018.

Henjes-Kunst, F., and Kreuzer, H., 2003, Mid-Paleozoic igneous activity in northern Victoria Land, Antarctica: implications of new geochronological data: Geologisches Jahrbuch B, v. 85, p. 271-302.

Hiess, J., Yi, K., Woodhead, J., Ireland, T., and Rattenbury, M., 2014, Gondwana margin evolution from zircon REE, $\mathrm{O}$ and Hf signatures of Western Province gneisses, Zealandia: Geological Society, London, Special Publications, v. 389, doi:10.1144/sp389.10.

Ireland, T. R., Floettmann, T., Fanning, C. M., Gibson, G. M., and Preiss, W. V., 1998, Development of the early Paleozoic Pacific margin of Gondwana from detrital-zircon ages across the Delamerian Orogen: Geology, v. 26, p. 243-246. doi:10.1130/00917613(1998)026<0243:dotepp $>2.3 . c 0 ; 2$.

Kemp, A. I. S., Hawkesworth, C. J., Collins, W. J., Gray, C. M., and Blevin, P. L., 2009, Isotopic evidence for rapid continental growth in an extensional accretionary orogen: The Tasmanides, eastern Australia: Earth and Planetary Science Letters, v. 284, p. 455-466. doi:10.1016/j.eps1.2009.05.011.

Kemp, A. I. S., Hawkesworth, C. J., Foster, G. L., Paterson, B. A., Woodhead, J. D., Hergt, J. M., Gray, C. M., and Whitehouse, M. J., 2007, Magmatic and Crustal Differentiation History of Granitic Rocks from Hf-O Isotopes in Zircon: Science, v. 315, p. 980-983. doi:10.1126/science. 1136154 .

Korhonen, F. J., Saito, S., Brown, M., Siddoway, C. S., and Day, J. M. D., 2010a, Multiple generations of granite in the Fosdick Mountains, Marie Byrd Land, West Antarctica; implications for polyphase intracrustal differentiation in a continental margin setting: Journal of Petrology, v. 51, p. 627-670. doi:10.1093/petrology/egp093.

Korhonen, F. J., Saito, S., Brown, M., and Siddoway, C. S., 2010b, Modeling multiple melt loss events in the evolution of an active continental margin: Lithos, v. 116, p. 230-248. doi:10.1016/j.lithos.2009.09.004.

Korhonen, F. J., Brown, M., Grove, M., Siddoway, C. S., Baxter, E. F., and Inglis, J. D., 2012, Separating metamorphic events in the Fosdick migmatite-granite complex, West Antarctica: Journal of Metamorphic Geology, v. 30, p. 165-192. doi:10.1111/j.15251314.2011.00961.x.

Kruskal, W. H., and Wallis, W. A., 1952, Use of Ranks in One-Criterion Variance Analysis: Journal of the American Statistical Association, v. 47, p. 583-621. doi:10.1080/01621459.1952.10483441.

Luyendyk, B. P., 1995, Hypothesis for Cretaceous rifting of East Gondwana caused by subducted slab capture: Geology, v. 23, p. 373-376. doi:10.1130/00917613(1995)023<0373: hfcroe $>2.3$.co;2.

Luyendyk, B.P., Cisowski, S., Smith, C.H., Richard, S. M., and Kimbrough, D.L., 1996, Paleomagnetic study of the northern Ford Ranges, western Marie Byrd Land, West Antarctica: a middle Cretaceous pole, and motion between West and East Antarctica? Tectonics, v. 15, p. 122-141. doi: 10.1029/95TC02524

McDonough, W. F., and Sun, S. s., 1995, The composition of the Earth: Chemical geology, v. 120, p. 223-253. doi:10.1016/0009-2541(94)00140-4. 
McFadden, R. R., Siddoway, C. S., Teyssier, C., and Fanning, C. M., 2010, Cretaceous oblique extensional deformation and magma accumulation in the Fosdick Mountains migmatitecored gneiss dome, West Antarctica: Tectonics, v. 29, TC4022. doi:10.1029/2009tc002492.

Miles, A., Graham, C., Hawkesworth, C., Gillespie, M., Dhuime, B., and Hinton, R., 2014, Using Zircon Isotope Compositions to Constrain Crustal Structure and Pluton Evolution: the Iapetus Suture Zone Granites in Northern Britain: Journal of Petrology, v. 55, p. 181207. doi:10.1093/petrology/egt065.

Millar, I. L., and Pankhurst, R. J., 1987, Rb-Sr geochronology of the region between the Antarctic Peninsula and the Transantarctic Mountains; Haag Nunataks and Mesozoic granitoids: Geophysical Monograph, v. 40, p. 151-160. doi:10.1029/GM040p0151.

Mortimer, N., Hoernle, K., Hauff, F., Palin, J. M., Dunlap, W. J., Werner, R., and Faure, K., 2006, New constraints on the age and evolution of the Wishbone Ridge, Southwest Pacific Cretaceous microplates, and Zealandia-West Antarctica breakup: Geology, v. 34, p. 185-188. doi:10.1130/g22168.1.

Muir, R. J., Ireland, T. R., Weaver, S. D., and Bradshaw, J. D., 1994, Ion microprobe U-Pb zircon geochronology of granitic magmatism in the Western Province of the South Island, New Zealand: Chemical geology, v. 113, p. 171-189. doi:10.1016/00092541(94)90011-6.

Muir, R. J., Ireland, T. R., Weaver, S. D., and Bradshaw, J. D., 1996, Ion microprobe dating of Paleozoic granitoids; Devonian magmatism in New Zealand and correlations with Australia and Antarctica: Chemical geology, v. 127, p. 191-210. doi:10.1016/00092541(95)00092-5.

Mukasa, S. B., and Dalziel, I. W. D., 2000, Marie Byrd Land, West Antarctica; evolution of Gondwana's Pacific margin constrained by zircon U-Pb geochronology and feldspar common-Pb isotopic compositions: Geological Society of America Bulletin, v. 112, p. 611-627. doi:10.1130/0016-7606(2000)112<0611:mblwae>2.3.co;2.

Nebel-Jacobsen, Y., Münker, C., Nebel, O., and Mezger, K., 2011, Precambrian sources of Early Paleozoic SE Gondwana sediments as deduced from combined $\mathrm{Lu}-\mathrm{Hf}$ and $\mathrm{U}-\mathrm{Pb}$ systematics of detrital zircons, Takaka and Buller terrane, South Island, New Zealand: Gondwana Research, v. 20, p. 427-442. doi:http://dx.doi.org/10.1016/j.gr.2010.11.014.

O'Neil, J. R., and Chappell, B. W., 1977, Oxygen and hydrogen isotope relations in the Berridale batholith: Journal of the Geological Society, v. 133, p. 559-571. doi:10.1144/gsjgs.133.6.0559.

Pankhurst, R. J., Millar, I. L., Grunow, A. M., and Storey, B. C., 1993, The pre-Cenozoic magmatic history of the Thurston Island crustal block, West Antarctica: Journal of Geophysical Research, v. 98, p. 11835-11849. doi:10.1029/93jb01157.

Pankhurst, R. J., Weaver, S. D., Bradshaw, J. D., Storey, B. C., and Ireland, T. R., 1998, Geochronology and geochemistry of pre-Jurassic superterranes in Marie Byrd Land, Antarctica: Journal of Geophysical Research, v. 103, p. 2529-2547. doi:10.1029/97jb02605.

Patiño Douce, A. E., and Harris, N., 1998, Experimental Constraints on Himalayan Anatexis: Journal of Petrology, v. 39, p. 689-710. doi:10.1093/petroj/39.4.689.

Paulsen, T. S., Encarnación, J., Grunow, A. M., Valencia, V. A., Pecha, M., Layer, P. W., and Rasoazanamparany, C , 013, Age and significance of 'outboard' high-grade 
1102

1103

1104

1105

1106

1107

1108

1109

1110

1111

1112

1113

1114

1115

1116

1117

1118

1119

1120

1121

1122

1123

1124

1125

1126

1127

1128

1129

1130

1131

1132

1133

1134

1135

1136

1137

1138

1139

1140

1141

1142

1143

1144

1145

1146

metamorphics and intrusives of the Ross orogen, Antarctica: Gondwana Research, v. 24, p. 349-358. doi:10.1016/j.gr.2012.10.004.

Paulsen, T. S., Encarnación, J., Grunow, A. M., Valencia, V. A., Layer, P. W., Pecha, M., Stump, E., Roeske, S., Thao, S., and Rasoazanamparany, C., 2015, Detrital mineral ages from the Ross Supergroup, Antarctica: Implications for the Queen Maud terrane and outboard sediment provenance on the Gondwana margin: Gondwana Research, v. 27, no. 1, p. 377-391, doi:10.1016/j.gr.2013.10.006.

Richard, S. M., Smith, C. H., Kimbrough, D. L., Fitzgerald, P. G., Luyendyk, B. P., and McWilliams, M. O., 1994, Cooling history of the northern Ford Ranges, Marie Byrd Land, West Antarctica: Tectonics, v. 13, p. 837-857. doi:10.1029/93tc03322.

Rowell, A. J., Rees, M. N., Dubendorfer, E. M., Wallin, E. T., Van Schmus, W. R., and Smith, E. I., 1993, An active Neoproterozoic margin: evidence from the Skelton Glacier area, Transantarctic Mountains: Journal of the Geological Society, v. 150, p. 677-682. doi:10.1144/gsjgs.150.4.0677.

Sagar, M. W., and Palin, J. M., 2013, Carboniferous U-Pb zircon age for S-type Karamea Suite Redjacket Granite, Paparoa Metamorphic Core Complex lower plate, northern Westland: New Zealand Journal of Geology and Geophysics, v. 56, p. 109-120. doi:10.1080/00288306.2013.788525.

Scott, J. M., Cooper, A. F., Palin, J. M., Tulloch, A. J., Kula, J., Jongens, R., Spell, T. L., and Pearson, N. J., 2009, Tracking the influence of a continental margin on growth of a magmatic arc, Fiordland, New Zealand, using thermobarometry, thermochronology, and zircon U-Pb and Hf isotopes: Tectonics, v. 28, p. TC6007. doi:10.1029/2009tc002489.

Scott, J., Muhling, J. R., Fletcher, I., Billia, M., Palin, J. M., Elliot, T., and Guenter, C., 2011, The relationship of Palaeozoic metamorphism and S-type magmatism on the paleoPacific Gondwana margin: Lithos, v. 127, p. 522-534. doi:10.1016/j.lithos.2011.09.008.

Skjerlie, K. P., and Johnston, A. D., 1993, Fluid-Absent Melting Behavior of an F-Rich Tonalitic Gneiss at Mid-Crustal Pressures: Implications for the Generation of Anorogenic Granites: Journal of Petrology, v. 34, p. 785-815. doi:10.1093/petrology/34.4.785.

Siddoway, C. S., Baldwin, S. L., Fitzgerald, P. G., Fanning, C. M., and Luyendyk, B. P., 2004a, Ross Sea mylonites and the timing of intracontinental extension within the West Antarctic rift system: Geology, v. 32, p. 57-60. doi:10.1130/g20005.1.

Siddoway, C. S., Richard, S. M., Fanning, C. M., and Luyendyk, B. P., 2004b, Origin and emplacement of a Middle Cretaceous gneiss dome, Fosdick Mountains, West Antarctica: Special Paper - Geological Society of America, v. 380, p. 267-294. doi: 10.1130/0-81372380-9.267.

Siddoway, C. S., and Fanning, C. M., 2009, Paleozoic tectonism on the East Gondwana margin: Evidence from SHRIMP U-Pb zircon geochronology of a migmatite, Äigranite complex in West Antarctica: Tectonophysics, v. 477, p. 262-277. doi: 10.1016/j.tecto.2009.04.021.

Smith, C. H., 1996, Migmatites of the Alexandra Mountains, West Antarctica: PressureTemperature conditions of formation and regional context: Geologisches Jahrbuch, v. B52, p. 169-178.

Solar, G.S., and Brown, M., 2001a, Petrogenesis of migmatites in Maine, USA: Possible source of peraluminous leucogranite in plutons: Journal of Petrology, v. 42, p. 789-823, doi:10.1093/petrology/42.4.789. 
1147

1148

1149

1150

1151

1152

1153

1154

1155

1156

1157

1158

1159

1160

1161

1162

1163

1164

1165

1166

1167

1168

1169

1170

1171

1172

1173

1174

1175

1176

1177

1178

1179

1180

1181

1182

1183

1184

1185

1186

1187

1188

1189

1190

1191

Storey, B. C., Leat, P. T., Weaver, S. D., Pankhurst, R. J., Bradshaw, J. D., and Kelley, S., 1999, Mantle plumes and Antarctica-New Zealand rifting; evidence from Mid-Cretaceous mafic dykes: Journal of the Geological Society of London, v. 156, p. 659-671. doi:10.1144/gsjgs.156.4.0659.

Storey, B. C., Pankhurst, R. J., and Johnson, A. C., 1994, The Grenville Province within Antarctica; a test of the SWEAT hypothesis: Journal of the Geological Society of London, v. 151, p. 1-4. doi:10.1144/gsjgs.151.1.0001.

Tera, F., and Wasserburg, G. J., 1972, U-Th-Pb systematics in three Apollo 14 basalts and the problem of initial $\mathrm{Pb}$ in lunar rocks: Earth and Planetary Science Letters, v. 14, p. $281-$ 304. doi:10.1016/0012-821X(72)90128-8.

Tochilin, C. J., Reiners, P. W., Thomson, S. N., Gehrels, G. E., Hemming, S. R., and Pierce, E. L., 2012, Erosional history of the Prydz Bay sector of East Antarctica from detrital apatite and zircon geo- and thermochronology multidating: Geochemistry, Geophysics, Geosystems, v. 13, p. Q11015. doi:10.1029/2012gc004364.

Tukey, J. W., 1977, Exploratory Data Analysis: Addison-Wesley, 688 pp.

Tulloch, A. J., Ramezani, J., Kimbrough, D. L., Faure, K., and Allibone, A. H., 2009, U-Pb geochronology of mid-Paleozoic plutonism in western New Zealand; implications for Stype granite generation and growth of the east Gondwana margin: Geological Society of America Bulletin, v. 121, p. 1236-1261. doi:10.1130/b26272.1.

Turnbull, R. E., Tulloch, A. J., and Ramezani, J., 2013, Zetland Diorite, Karamea Batholith, west Nelson; field relationships, geochemistry and geochronology demonstrate links to the Carboniferous Tobin Suite: New Zealand Journal of Geology and Geophysics, v. 56, p. 83-99. doi:10.1080/00288306.2013.775166.

Valley, J. W., Chiarenzelli, J. R., and McLelland, J. M., 1994, Oxygen isotope geochemistry of zircon: Earth and Planetary Science Letters, v. 126, p. 187-206. doi:10.1016/0012821X(94)90106-6.

Valley, J. W., Kitchen, N., Kohn, M. J., Niendorf, C. R., and Spicuzza, M. J., 1995, UWG-2, a garnet standard for oxygen isotope ratios; strategies for high precision and accuracy with laser heating: Geochimica et Cosmochimica Acta, v. 59, p. 5223-5231. doi: 10.1016/0016-7037(95)00386-X

Valley, J. W., Kinny, P. D., Schulze, D. J., and Spicuzza, M. J., 1998, Zircon megacrysts from kimberlite: oxygen isotope variability among mantle melts: Contributions to Mineralogy and Petrology, v. 133, p. 1-11. doi:10.1007/s004100050432.

Valley, J. W., Bindeman, I. N., and Peck, W. H., 2003, Empirical calibration of oxygen isotope fractionation in zircon: Geochimica et Cosmochimica Acta, v. 67, p. 3257-3266. doi:10.1016/s0016-7037(03)00090-5.

Veevers, J. J., 2012, Reconstructions before rifting and drifting reveal the geological connections between Antarctica and its conjugates in Gondwanaland: Earth-Science Reviews, v. 111, p. 249-318. doi:10.1016/j.earscirev.2011.11.009.

Vervoort, J. D., and Jonathan Patchett, P., 1996, Behavior of hafnium and neodymium isotopes in the crust: Constraints from Precambrian crustally derived granites: Geochimica et Cosmochimica Acta, v. 60, p. 3717-3733. doi:10.1016/0016-7037(96)00201-3.

Vervoort, J. D., and Blichert-Toft, J., 1999, Evolution of the depleted mantle: Hf isotope evidence from juvenile rocks through time: Geochimica et Cosmochimica Acta, v. 63, p. 533-556. doi:10.1016/S0016-7037(98)00274-9. 
Vervoort, J. D., Patchett, P. J., Blichert-Toft, J., and Albarède, F., 1999, Relationships between $\mathrm{Lu}-\mathrm{Hf}$ and $\mathrm{Sm}-\mathrm{Nd}$ isotopic systems in the global sedimentary system: Earth and Planetary Science Letters, v. 168, p. 79-99. doi:10.1016/S0012-821X(99)00047-3.

Vetter, U., and Tessensohn, F., 1987, S- and I-Type granitoids of North Victoria Land, Antarctica, and their inferred geotectonic setting: Geologische Rundschau, v. 76, p. $233-$ 243. doi:10.1007/BF01820585.

Wandres, A.M. and Bradshaw, J.D. 2005. New Zealand tectonostratigraphy and implications from conglomeratic rocks for the configuration of the SW Pacific of Gondwana. In: Vaughan, A.P.M., Leat, P.T., and Pankhurst, R (Eds), Terrane Processes at the Margin of Gondwana. Geological Society, London, Special Publication v. 246, p. 179-206. doi: 10.1144/GSL.SP.2005.246.01.06.

Weaver, S. D., Adams, C. J., Pankhurst, R. J., and Gibson, I. L., 1992, Granites of Edward VII Peninsula, Marie Byrd Land; anorogenic magmatism related to Antarctic-New Zealand rifting: Special Paper - Geological Society of America, v. 272, p. 281-290. doi:10.1130/SPE272-p281.

Weaver, S. D., Bradshaw, J. D., and Adams, C. J., 1991, Granitoids of the Ford Ranges, Marie Byrd Land, Antarctica, Geological Evolution of Antarctica, Volume 5: International, Cambridge University Press : Cambridge - New York, International, p. 345-351.

Weaver, S. D., Storey, B. C., Pankhurst, R. J., Mukasa, S. B., DiVenere, V. J., and Bradshaw, J. D., 1994, Antarctica-New Zealand rifting and Marie Byrd Land lithospheric magmatism linked to ridge subduction and mantle plume activity: Geology, v. 22, p. 811-814. doi:10.1130/0091-7613(1994)022<0811:anzram>2.3.co;2.

Yakymchuk, C., Siddoway, C. S., Fanning, C. M., McFadden, R., Korhonen, F. J., and Brown, M., 2013a, Anatectic reworking and differentiation of continental crust along the active margin of Gondwana; a zircon Hf-O perspective from West Antarctica: Special Publication - Geological Society of London v. 383. doi:10.1144/sp383.7.

Yakymchuk, C., Brown, M., Ivanic, T. J., and Korhonen, F. J., 2013b, Leucosome distribution in migmatitic paragneisses and orthogneisses: A record of self-organized melt migration and entrapment in a heterogeneous partially-molten crust: Tectonophysics, v. 603, p. 136154. doi:10.1016/j.tecto.2013.05.022.

Yakymchuk, C., Brown, M., Clark, C., Korhonen, F. J., Piccoli, P. M., Siddoway, C. S., Taylor, R. J. M., and Vervoort, J. D., 2015, Decoding polyphase migmatites using geochronology and phase equilibria modelling: Journal of Metamorphic Geology. doi: 10.1111/jmg. 12117.

\section{FIGURE CAPTIONS}

Figure 1. (A) Geometrical reconstruction of the East Gondwana active convergent margin (modified from Veevers, 2012, Fig. 4). (B) Map of part of Antarctica to show locations referred to in the text. 
1234 Figure 2. The inset at the top, left shows the location of the study area in western Marie Byrd

1235 Land in West Antarctica. The main map shows sample localities in the study area. The thick

1236 dashed line separating the Ross Province from the Amundsen Province is taken from Pankhurst

1237 et al. (1998). The inset at the bottom, right shows sample localities in the Fosdick migmatite-

1238 granite complex.

1240 Figure 3. Histograms and normalized probability distribution curves of U-Pb ages retrieved

1241 from detrital zircon in the Swanson Formation (A-C) and metasedimentary rocks (D-F)

1242 outcropping in western Marie Byrd Land. All data from Table DR6 are plotted. (G) inherited

1243 grains (> $400 \mathrm{Ma}$ ) in the Ford Granodiorite suite, Devonian-Carboniferous granites, and

1244 diatexites (data from Pankhurst et al., 1998; Siddoway and Fanning, 2009; Korhonen et al., 1245 2010b; Yakymchuk et al., 2013a; this study).

1247 Figure 4. Cathodoluminescence images of representative zircon grains from the Swanson

1248 Formation and the Ford Granodiorite suite as well as Devonian-Carboniferous diatexites and

1249 granites from the Fosdick migmatite-granite complex. Ellipses mark the location of $\mathrm{U}-\mathrm{Pb}, \mathrm{O}$ and

1250 Hf isotope spot analyses. Cathodoluminescence images were collected on different dates and so

1251 exhibit some variation in quality/sharpness. The contrast of images of individual zircons was

1252 adjusted to best display internal zoning.

1254 Figure 5. U-Pb Tera-Wasserberg (1972) concordia and probability density plots of zircon data 1255 from the Ford Granodiorite suite and Devonian-Carboniferous diatexites and granites from the 1256 Fosdick migmatite-granite complex. Data-point error ellipses are at 95\% confidence. Age 
1257 uncertainties are reported at $\sigma$ confidence

1259 Figure 6. Major and trace element data for samples as determined by XRF. Ford Granodiorite 1260 suite samples include data from Korhonen et al. (2010a), Weaver et al. (1992), Pankhurst et al. 1261 (1998) and Tulloch et al. (2009) as well as the new data from this study. FeO* represents total 1262 iron as ferrous. Trace elements are plotted as parts per million (ppm).

1264 Figure 7. Chondrite-normalized (McDonough and Sun, 1995) rare earth element patterns of 1265 newly-analyzed samples from this study as well as additional data from Korhonen et al. (2010a) 1266 and Tulloch et al. (2009).

1268 Figure 8. $\mathrm{Sr}-\mathrm{Nd}$ isotopic compositions at $360 \mathrm{Ma}$ of samples from this study and additional data 1269 from Korhonen et al. (2010a), Weaver et al. (1992), and Pankhurst et al. (1998). The two grey 1270 lines connect samples that represent exemplar isotopic end members of the Swanson Formation 1271 and the Ford Granodiorite suite, respectively, chosen so that the resulting mixing curves enclose 1272 the range of isotopic compositions for the granites and the diatexite. Tick marks along mixing 1273 curve are at $10 \%$ increments.

1275 Figure 9. (A) Hf evolution diagram for detrital zircons from the Swanson Formation. Reference 1276 evolution line for depleted mantle (DM) is from Vervoort and Blichert-Toft (1999) and for new 1277 crust is from Dhuime et al. (2011). (B) Hf and O isotope values of detrital zircon from a sample 1278 of calc-silicate gneiss $(8 \mathrm{D} 27-10)$. The $\delta^{18} \mathrm{O}$ value of the mantle $(5.3 \pm 0.6 \%$ ) is from Valley et al. 1279 (1998). Newly crystallized zircons derived from partial melting of metasedimentary rocks are 
1280 expected to have $\delta^{18} \mathrm{O}$ values of $\sim 8.5-12 \%$.

1282 Figure 10. Plots of $\delta^{18}$ Oand $\varepsilon \mathrm{Hf}_{\mathrm{t}}$ versus ${ }^{238} \mathrm{U} /{ }^{206} \mathrm{~Pb}$ crystallization age for zircons from four Ford

1283 Granodiorite suite samples and two diatexites Uncertainties are $\pm \sigma$ for $\delta^{18} \mathrm{O}$ and $\varepsilon \mathrm{Hf}_{\mathrm{t}}$. The $\varepsilon \mathrm{Hf}_{\mathrm{t}}$

1284 for new crust is taken from Dhuime et al. $(2011 ;+12.2 \pm 1.1)$ and $\delta^{18} \mathrm{O}$ for the mantle is from

1285 Valley et al. $\left(1998 ; 5.3 \pm 0.6 \%\right.$ ). The $\varepsilon \mathrm{Hf}_{\mathrm{t}}$ (median value of -11.7 and an interquartile range of -

12863.5 to -19.9$)$ and $\delta^{18} \mathrm{O}(8.5-12 \%$, with a mean value of $10.5 \%$ ) values chosen for the Swanson

1287 Formation are discussed in the text.

1289 Figure 11. Hf evolution diagram to show data for detrital zircons from the Swanson Formation, 1290 igneous zircon from the Ford Granodiorite suite, zircon from the gneiss at Haag Nunataks (from 1291 Flowerdew et al., 2007), and zircon from granite clasts (from Goodge et al., 2013). Reference 1292 evolution lines for the depleted mantle (DM) are from Vervoort and Blichert-Toft (1999) and for 1293 new crust are from Dhuime et al. (2011). The dark grey $\varepsilon H f$ evolution lines from the gneiss at 1294 Haag Nunatak and ca. 1.2 Ga granite clast were constructed using the average ${ }^{176} \mathrm{Lu} /{ }^{177} \mathrm{Hf}$ value 1295 of crustal rocks (0.0115) and the light grey fields extend to $\pm 1 \sigma$ of this average (Vervoort and 1296 Patchett, 1996; Vervoort et al., 1999).

1298 Figure 12. Box-and-whisker plots for $\varepsilon \mathrm{Hf}_{\mathrm{t}}$ and $\delta{ }^{18}$ Oversus ${ }^{238} \mathrm{U} /{ }^{206} \mathrm{~Pb}$ zircon crystallization age 1299 for members of the Ford Granodiorite suite (dark grey boxes), and samples of the associated 1300 granites (open boxes) and diatexites (light gray boxes). The box represents the interquartile range 1301 (the middle $50 \%$ of the data from the $25^{\text {th }}$ to the $75^{\text {th }}$ percentile), the whiskers extend to 1.5 times 1302 the interquartile range and the crosses represent outliers. Data for samples MB.214, MB.219, 
1303 M5-G175 and C5-Is51a are from Pankhurst et al. (1998) and Yakymchuk et al. (2013a). The

1304 crystallization age for sample Y1-IG071 is taken to be $360 \mathrm{Ma}$, as discussed in the text. The $\mathrm{EHf}_{\mathrm{t}}$

1305 for new crust is taken from Dhuime et al. $(2011 ;+12.2 \pm 1.1)$ and $\delta^{18} \mathrm{O}$ for the mantle is from

1306 Valley et al. $\left(1998 ; 5.3 \pm 0.6 \%\right.$ ). The $\varepsilon \mathrm{Hf}_{\mathrm{t}}$ (median value of -11.7 and an interquartile range of -

13073.5 to -19.9$)$ and $\delta^{18} \mathrm{O}(8.5-12 \%$, with a mean value of $10.5 \%)$ values chosen for the Swanson

1308 Formation are discussed in the text.

1310 Figure. 13. (A) Plots of $\delta^{18}$ Oversus $\varepsilon \mathrm{Hf}_{\mathrm{t}}$ for individual zircons from the four newly-analyzed

1311 members of the Ford Granodiorite suite. Binary mixing lines connect representative end-

1312 members of each of the sources modeled - the mantle (Juv) and the Swanson Formation (SF).

1313 Small filled circles on each line display 10\% increments. (B) Field to show the range of $\delta^{18}$ Oand

$1314 \varepsilon \mathrm{Hf}_{\mathrm{t}}$ values for the data shown in $(\mathrm{A})$. Binary mixing lines between anatectic melt derived from

1315 the Ford Granodiorite suite (FGD) and Swanson Formation either assimilated en masse or as

1316 anatectic melt separated from the Swanson Formation. Two representative end-member $\varepsilon \mathrm{Hf}_{\mathrm{t}}$ and

$1317 \delta^{18} \mathrm{O}$ values are used to evaluate the contribution from the oldest and most juvenile end-members

1318 of the Ford Granodiorite suite. (C) Plots of $\delta^{18} \mathrm{O}$ and $\varepsilon \mathrm{Hf}_{\mathrm{t}}$ values from individual zircons from

1319 granites and diatexites in the Fosdick migmatite-granite complex. The field for the full range of

$1320 \delta^{18} \mathrm{O}$ and $\varepsilon \mathrm{Hf}_{\mathrm{t}}$ values retrieved from the Ford Granodiorite suite represents one of the end-

1321 member source compositions used in the modeling. Multiple binary mixing scenarios for the

1322 petrogenesis of the granites and diatexites are evaluated. Also shown in all three figures are end-

1323 member $\varepsilon H f$ values for the mantle, corresponding to CHUR and a value expected for new crust,

1324 respectively. The $\delta^{18} \mathrm{O}$ value of the mantle is $53 \pm 06 \%$ (Valley et al., 1998). The $\varepsilon_{\mathrm{Hf}}(\mathrm{median}$

1325 value of -11.7 and an interquartile range of -3.5 to -19.9$)$ and $\delta^{18} \mathrm{O}(8.5-12 \%$, with a mean value 
1326 of $10.5 \%$ ) values chosen for the Swanson Formation.

1328 Figure 14. Ternary $(\mathrm{Na}+\mathrm{Ca})-\left(\mathrm{Fe}^{*}+\mathrm{Mg}+\mathrm{Ti}\right)-\mathrm{K}$ plot (cf. Solar and Brown, 2001) of the full suite

1329 of granites and diatexites to assess different petrogenetic models. Starting materials and

1330 experimental melt compositions are taken from Skjerlie et al. (1993) and Patiño Douce and

1331 Harris (1998). The experimental melts from Skjerlie et al. (1993) were used as proxies for melts

1332 derived from the Ford Granodiorite suite while the experimental results of Patiño Douce and

1333 Harris (1998) were used to infer melt compositions derived from the Swanson Formation. The

1334 shaded areas represent the range of possible granite and diatexite compositions that may be

1335 achieved by assimilation or mixing between Ford Granodiorite suite compositions and Swanson

1336 Formation en masse or as anatectic melt separated from residue.

1338 Figure 15. Compilation of whole rock $\mathrm{Nd}(\mathbf{A})$ and zircon $\mathrm{Hf}(\mathbf{B})$ isotope data for igneous rocks

1339 from the eastern Gondwana margin. Data sources include: the Ford Ranges of western Marie

1340 Byrd Land (Pankhurst et al., 1998; Korhonen et al., 2010; Yakymchuk et al., 2013a; this study),

1341 the Western Province of New Zealand (Muir et al., 1996; Scott et al., 2009; Tulloch et al., 2009),

1342 north Victoria Land (Borg et al., 1986; Armienti et al., 1990; Borg and DePaolo, 1991;

1343 Bomparola et al., 2007), and the Tasmanides (Kemp et al., 2007; Kemp et al., 2009 and

1344 references therein). Reference evolution lines for the depleted mantle (DM) are from Vervoort

1345 and Blichert-Toft (1999) for Hf and DePaolo (1981) for $\mathrm{Nd}$. Hf isotope values for new crust are

1346 from Dhuime et al. (2011). 


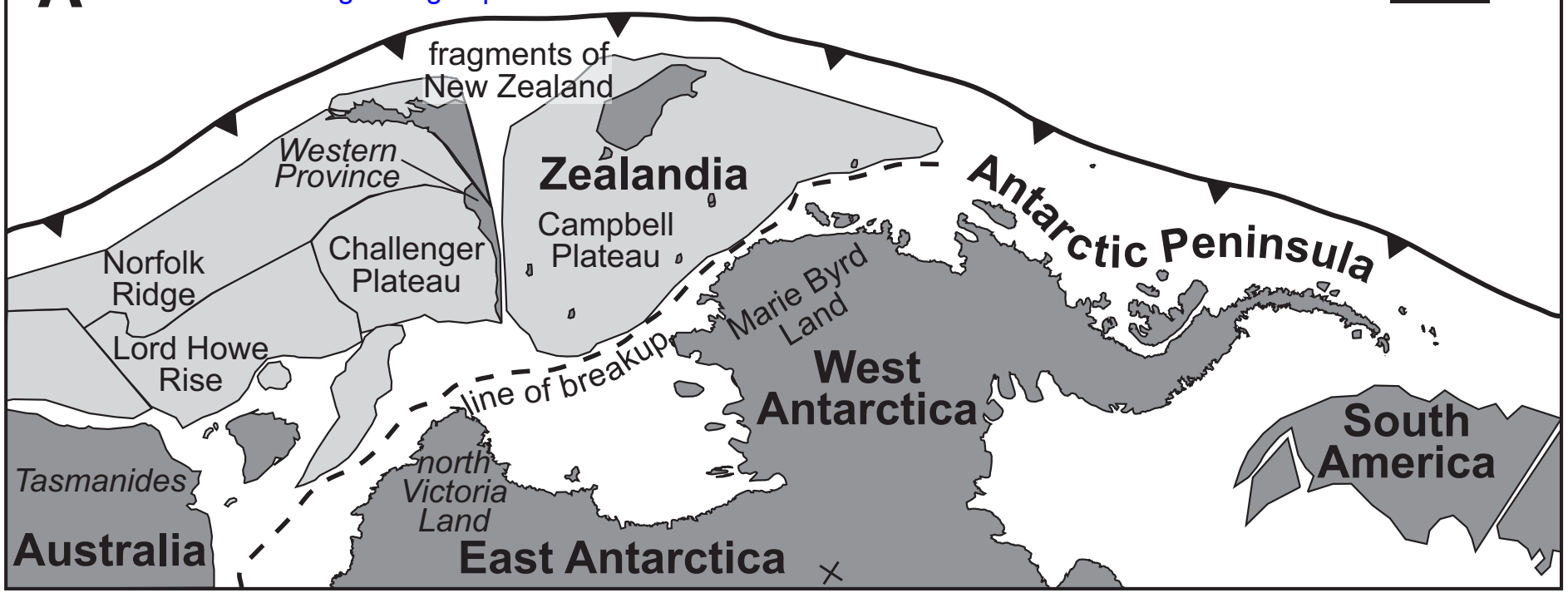

B

East Antarctica

$500 \mathrm{~km}$

Executive

Committee

Range

Ruppert Coast

Ford

Ranges

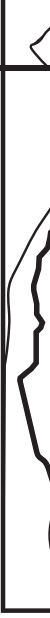

\section{Ross}

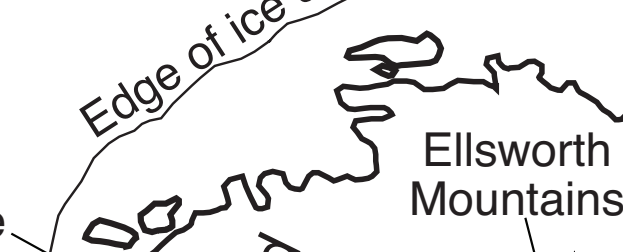

$90^{\circ} \mathrm{W}$

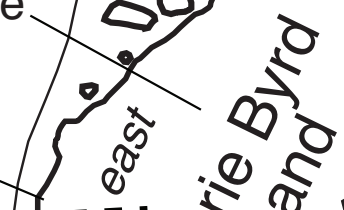

$\Delta$
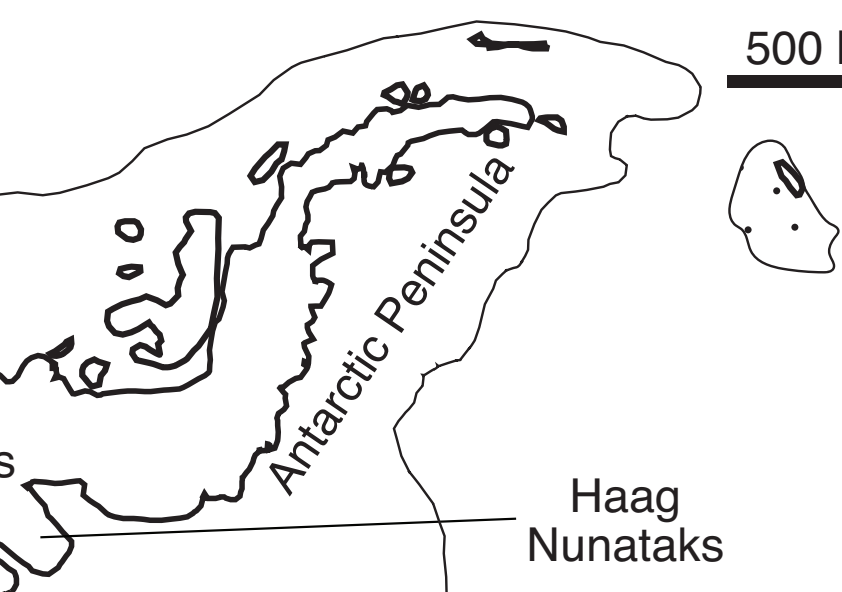

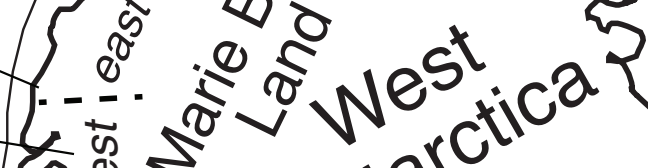

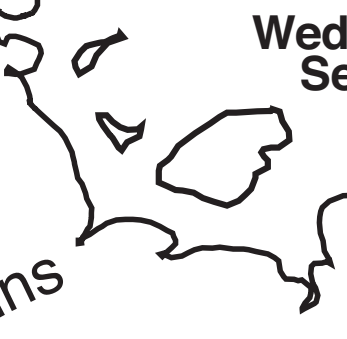

Weddell

Sea

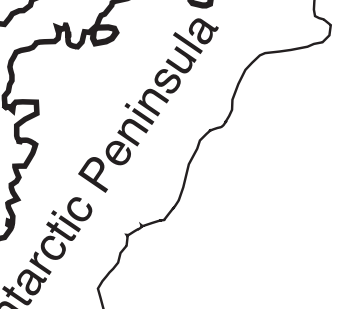

Gamburtsev

East Antarctica

Haag subglacial

Vostock

Subglacial $\triangle 90^{\circ} \mathrm{E}$ $\triangle$ Mountains

Prydz Bay

\section{Figure 1}

Yakymchuk et al. 


\section{Figure 2}

Click here to download Figure: fig2.eps

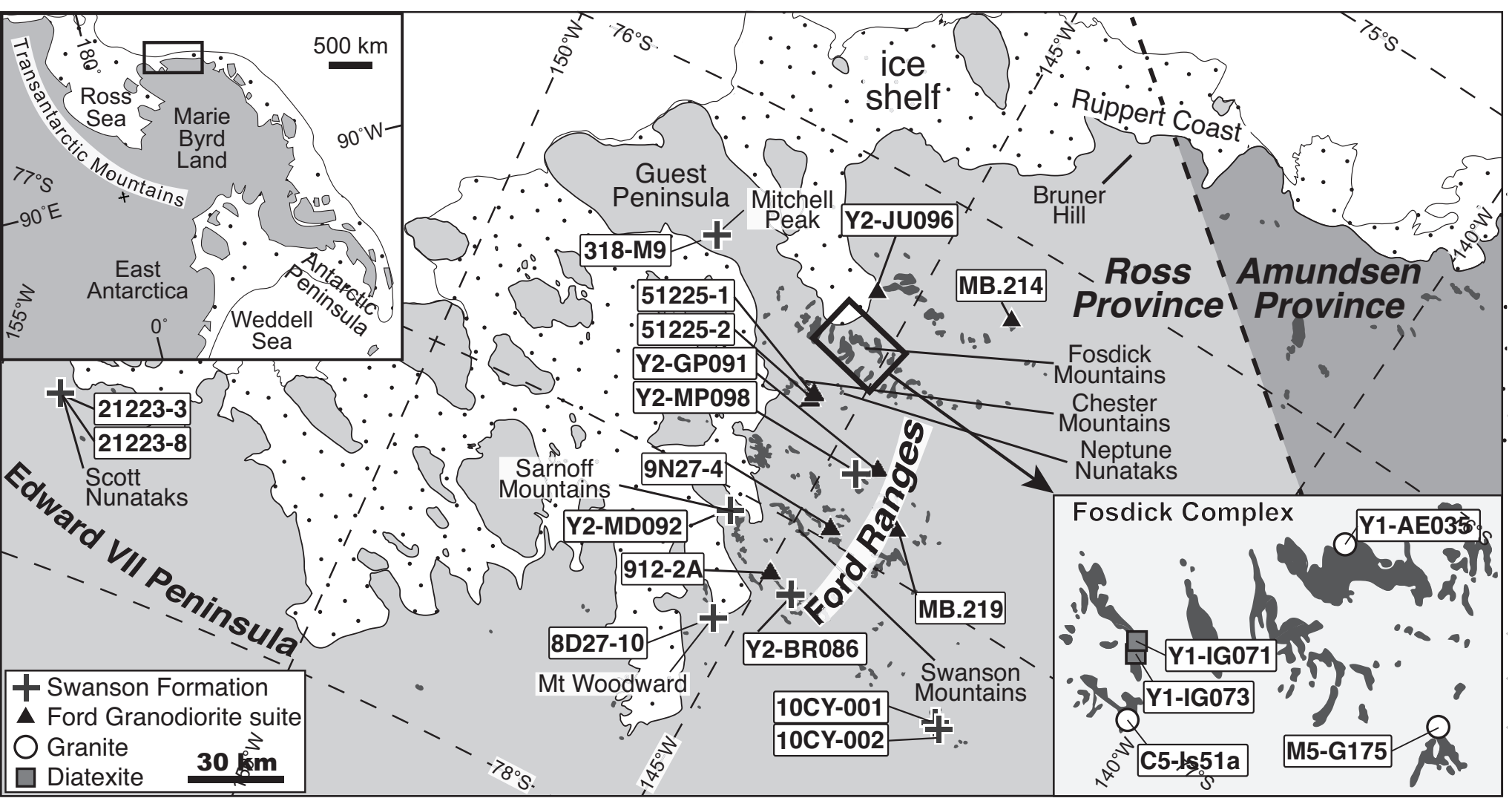

\section{Yakymchuk et al. \\ Figure 2}




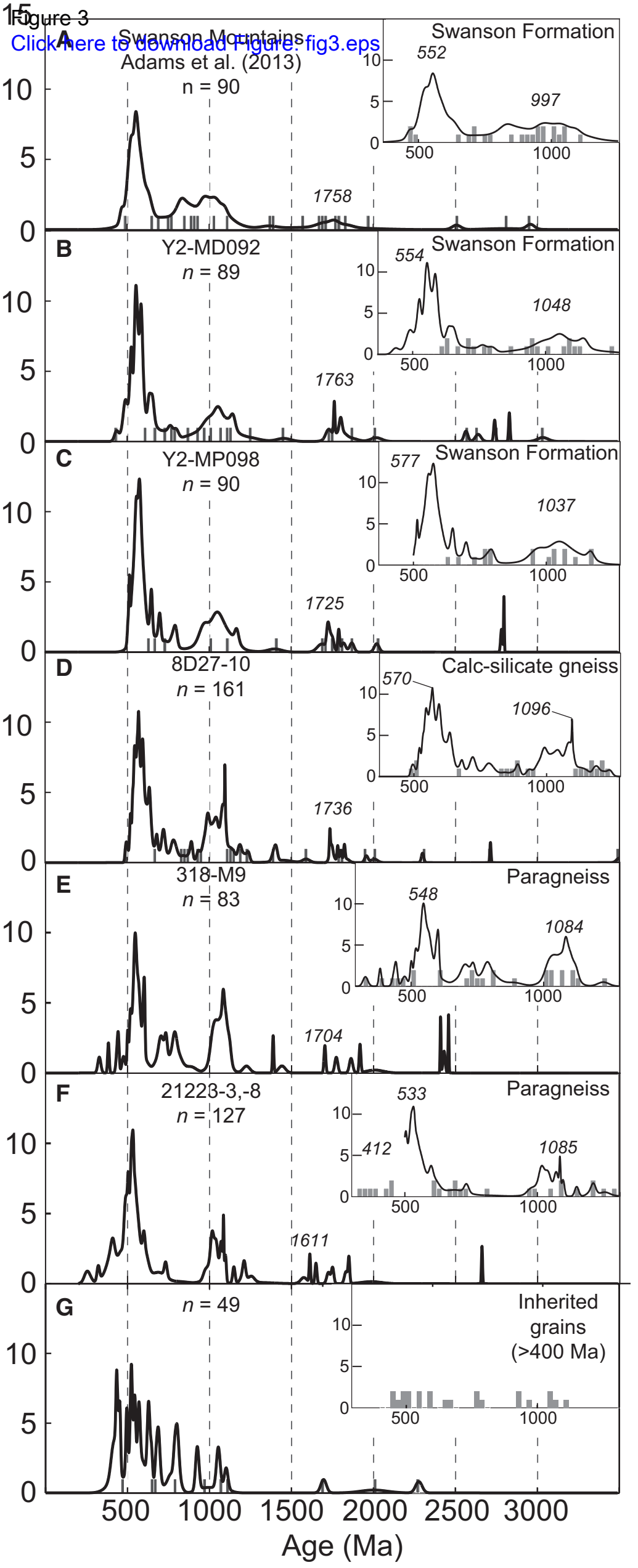

Figure 3

Yakymchuk et al. 


\section{Figure 4}

Click here to download high resolution image

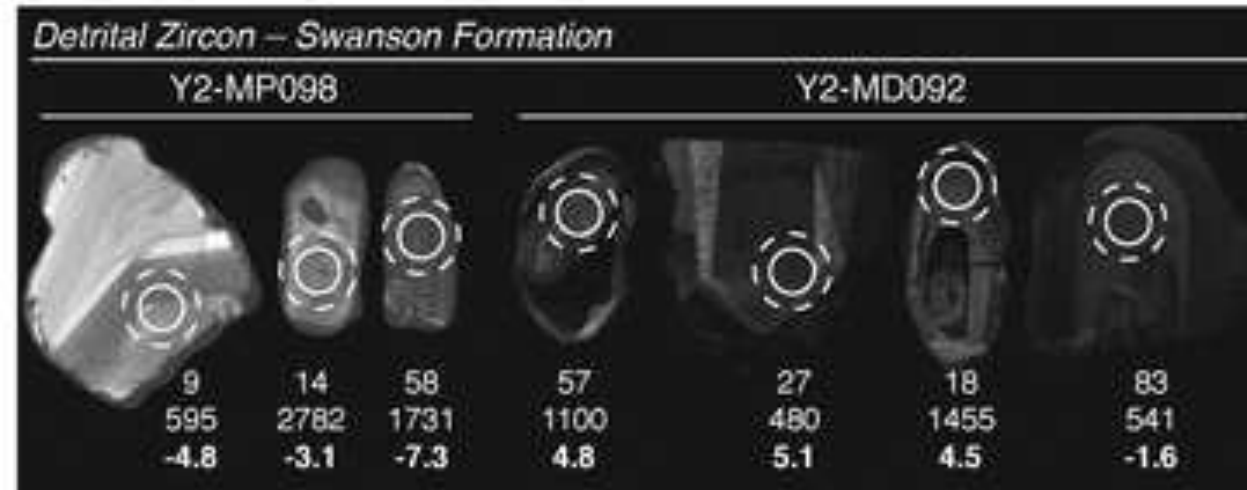

Ford Granodionite suite.

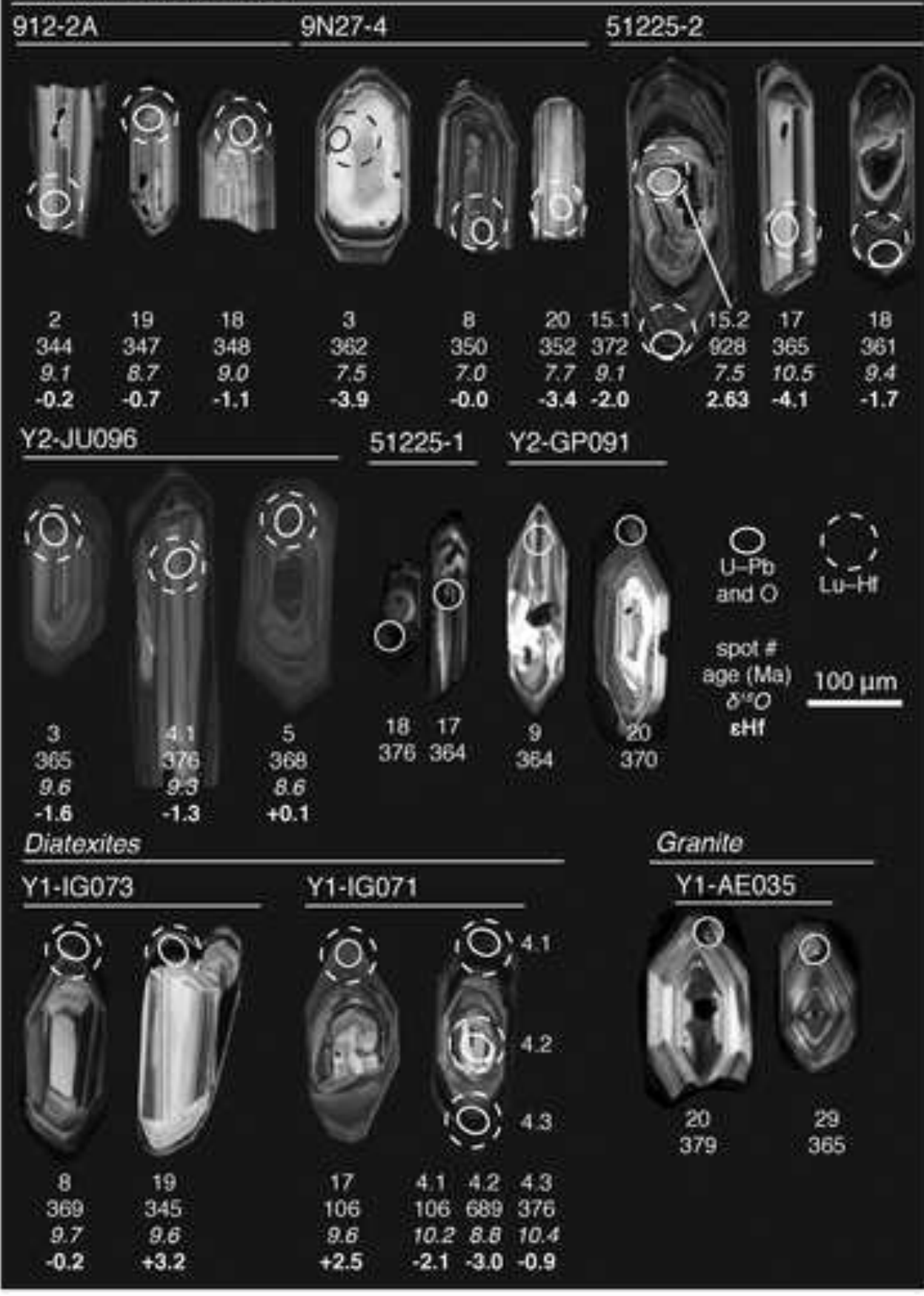

Figure 4

Yakymchuk et al. 


\section{Figure 5}

Click here to download Figure: fig5.eps
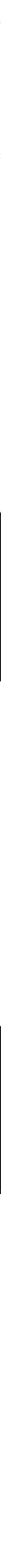

Figure 5

Yakymchuk et al. 


\section{Figure 7}

Click here to do ford Figure: fig7_R2.eps Swanson Formation

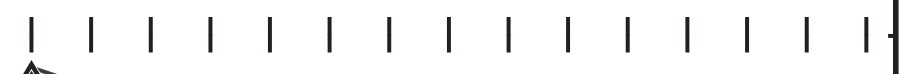

Ford Granodiorite suite

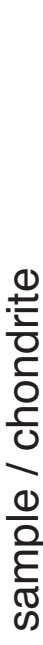
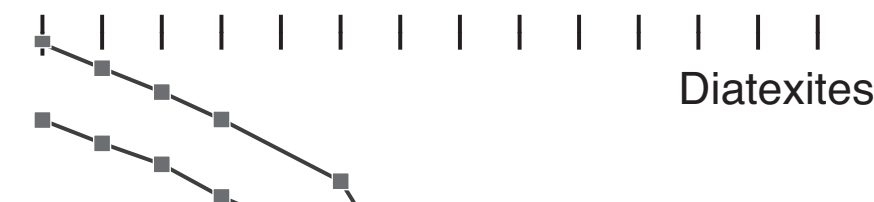

10

$\begin{array}{lllllllllllllll}1 & 1 & 1 & 1 & 1 & 1 & 1 & 1 & 1 & 1 & 1 & 1 & 1 & 1 & 1\end{array}$ Devonian-Carboniferous granites

100

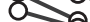

8
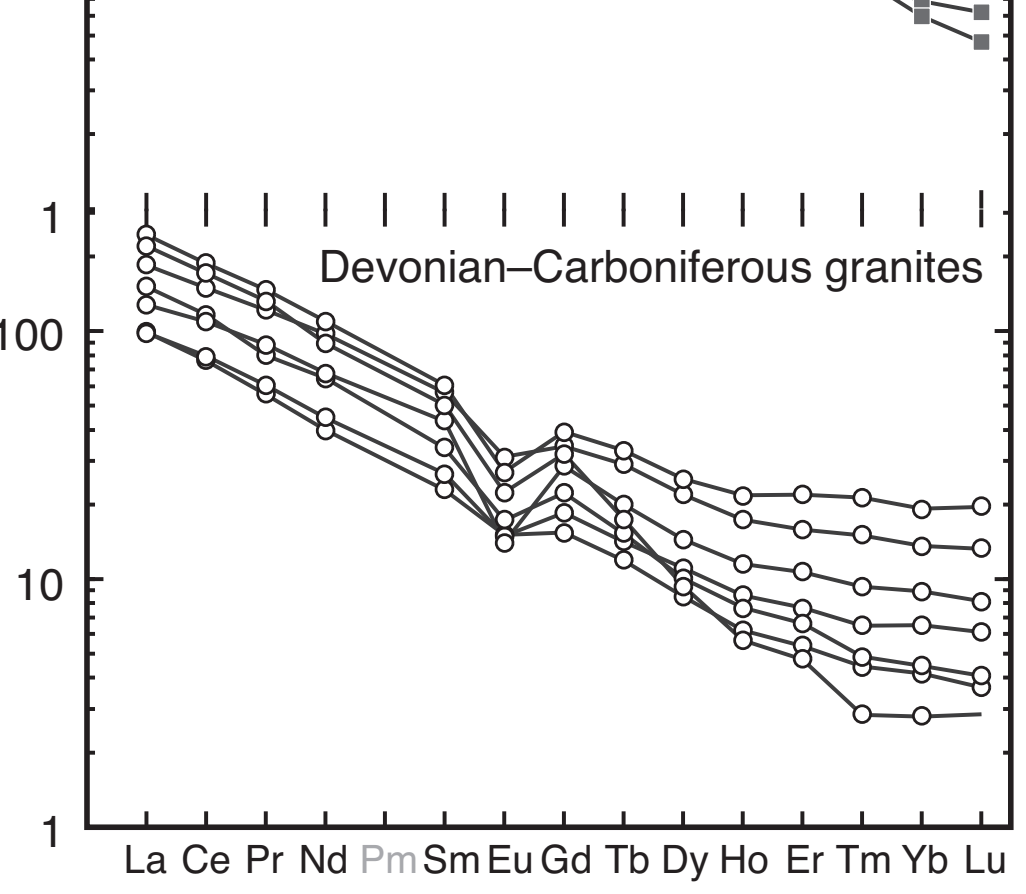

Figure 7

Yakymchuk et al. 


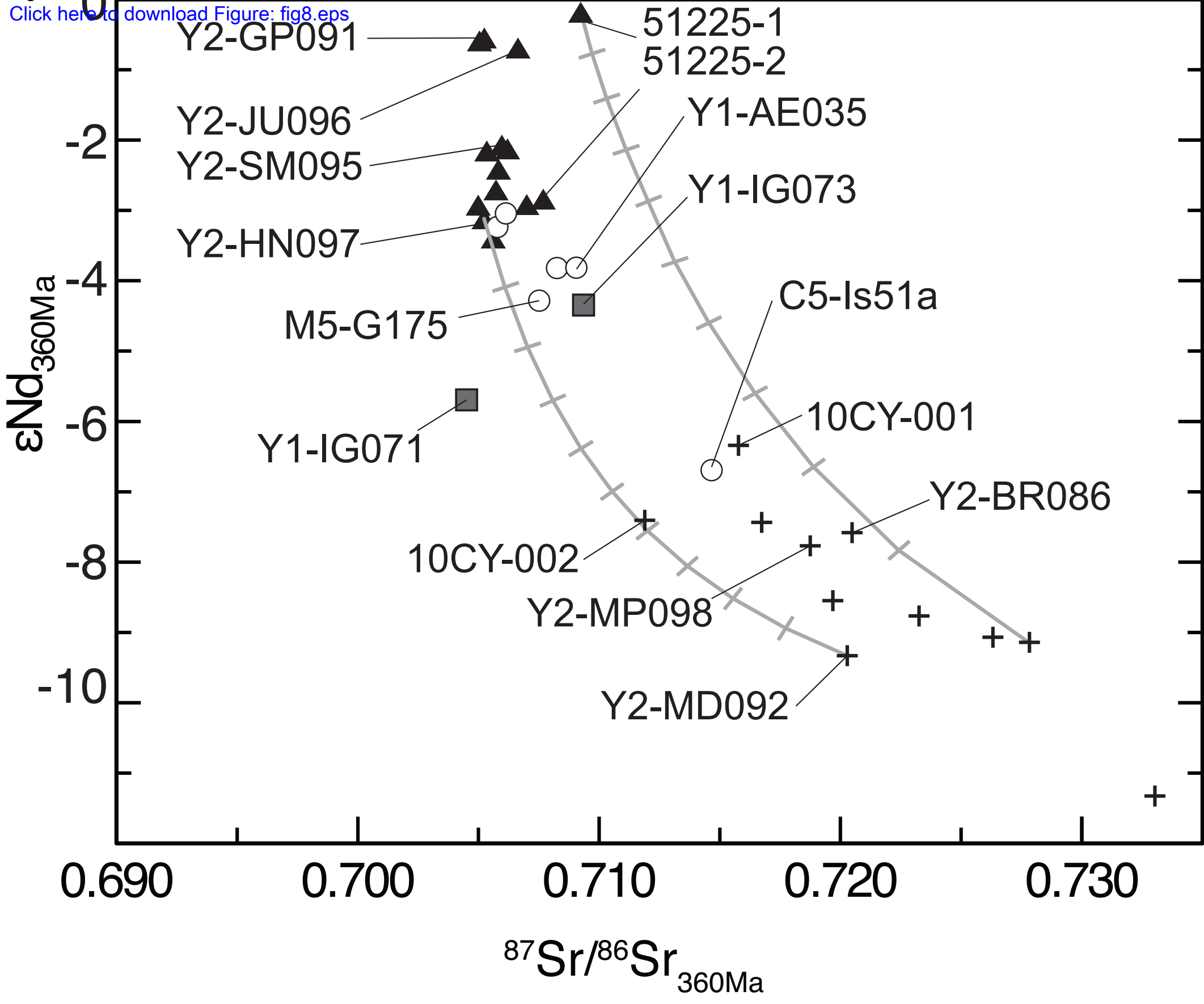

Ford Ranges

+ Swanson Formation

- Ford Granodiorite suite
Fosdick migmatitegranite complex

O Granite

$\square$ Diatexite

Figure 8

Yakymchuk et al. 
Figure 1015

Click here to lown i ad Figrte: fig10.eps

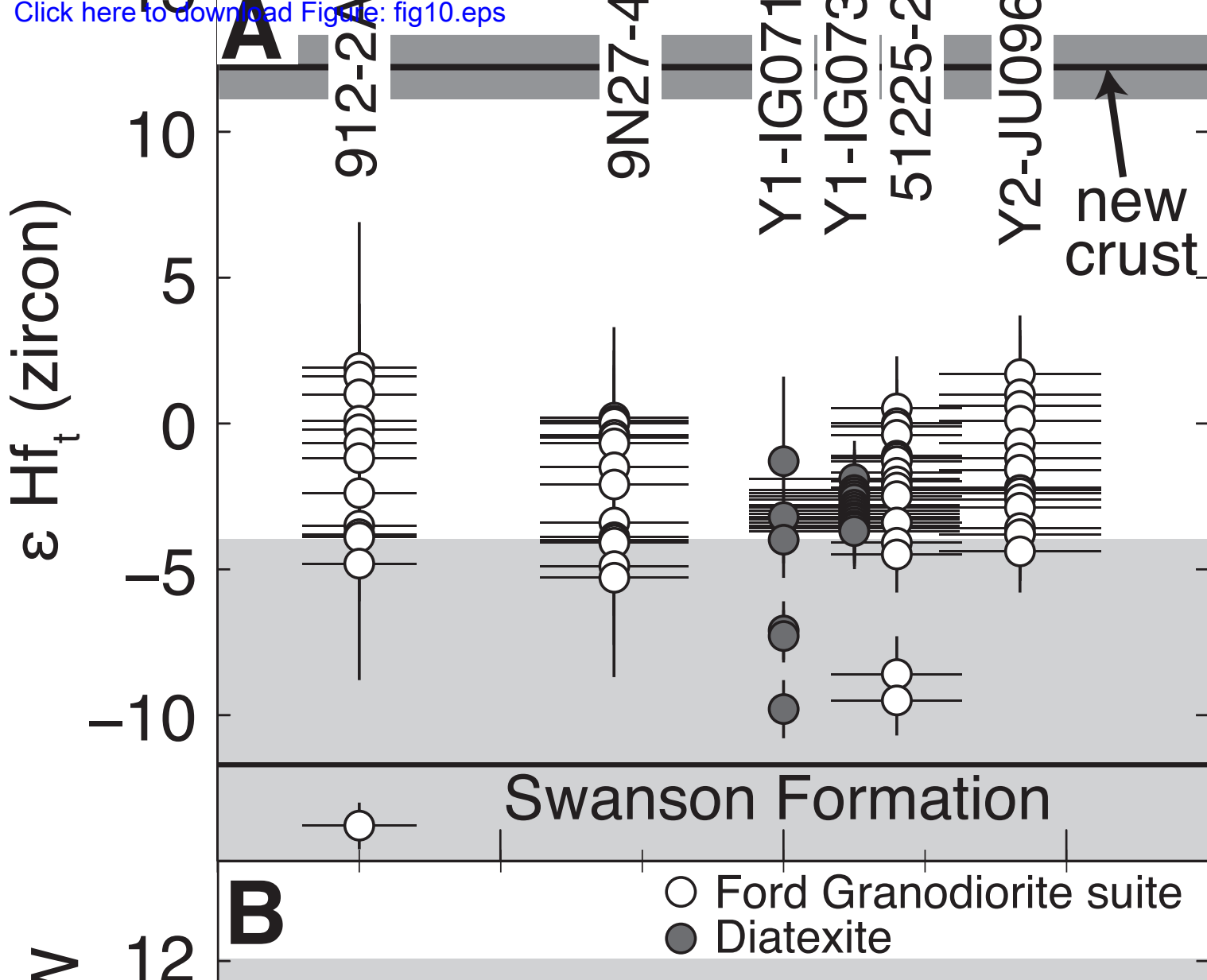

$\sum_{\substack{3 \\ 0 \\>}}^{3}$

$12 B$

Swanson

Formation

০ঃ

10
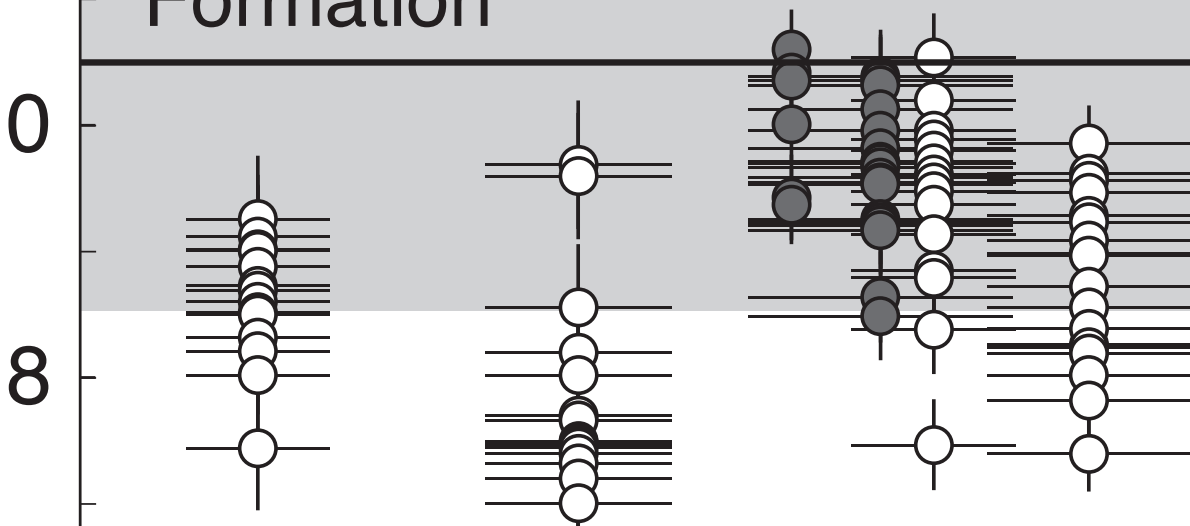

6

mantle

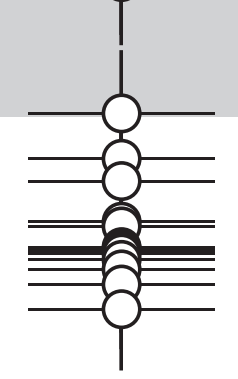

$\infty$

io

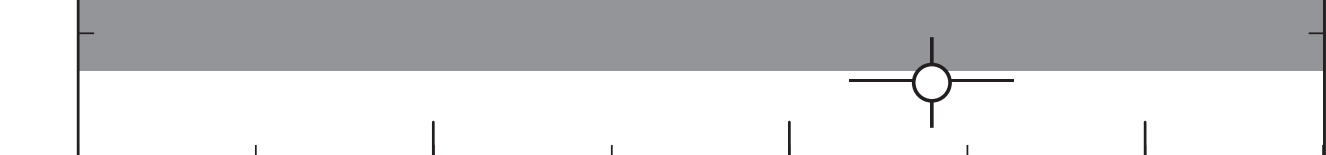

$340 \quad 350$

360

370

Age (Ma)

Figure 10

Yakymchuk et al. 


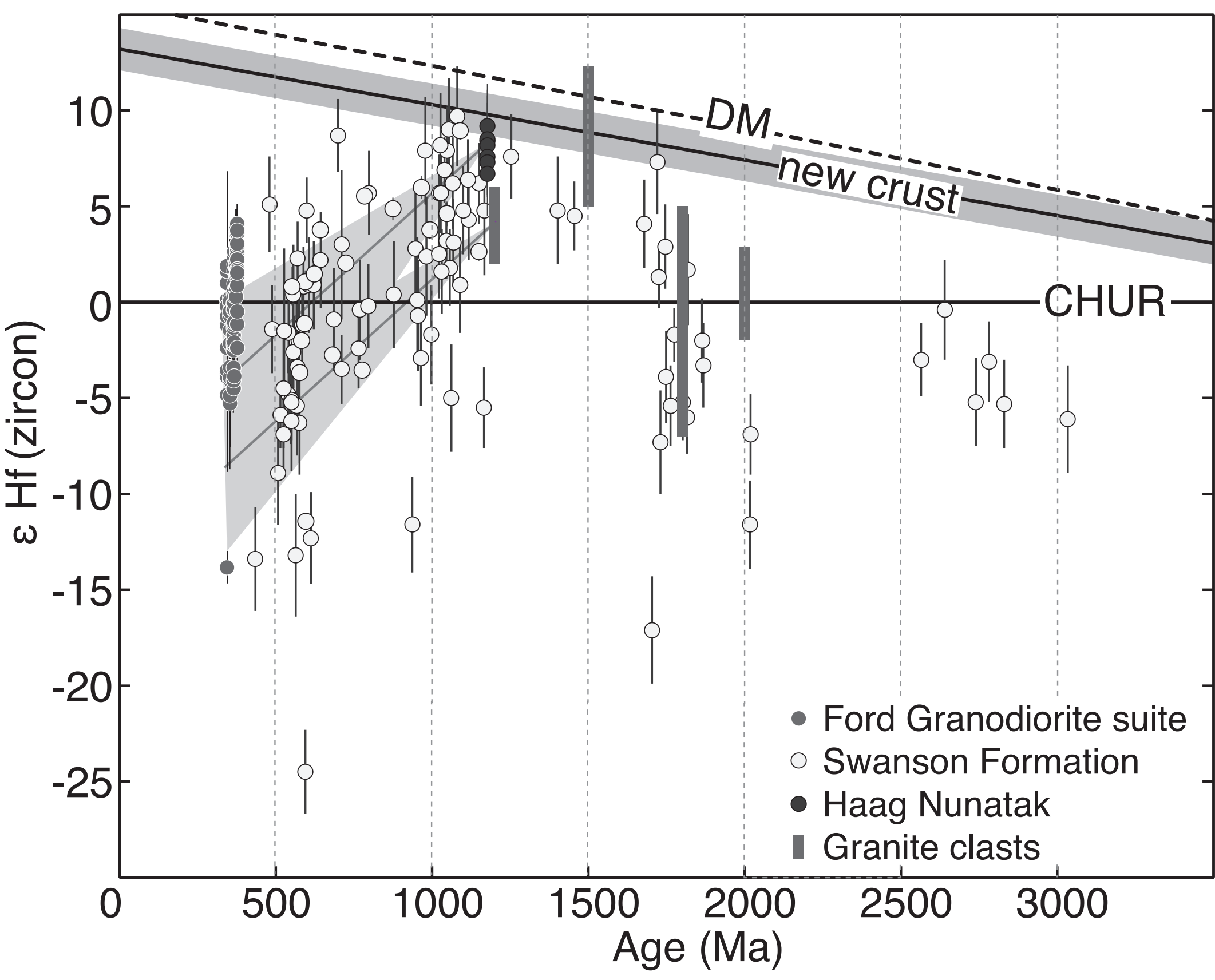

Figure 11

Yakymchuk et al. 


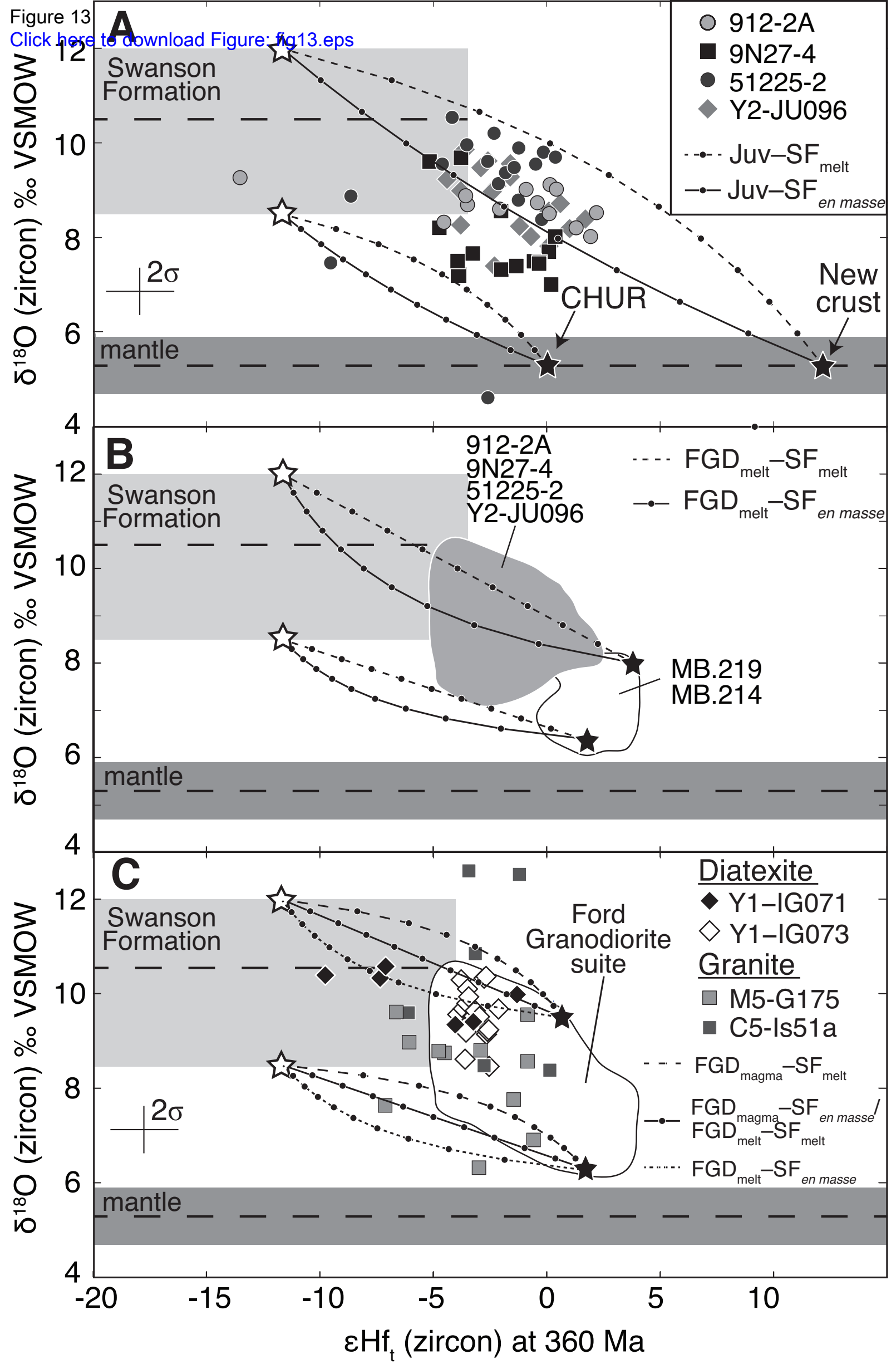

Figure 13

Yakymchuk et al. 


\section{$\left(\mathrm{Fe}^{*}+\mathrm{Mg}+\mathrm{Ti}\right) \mathrm{mol} \%$}

Experimental melt compositions Material Glass

\section{世 1 Skerlie and Johnston (1993) \\ Patiño-Douce and Harris, (1998)}

+ Swanson Formation

- Ford Granodiorite suite

O Granite

$\square$ Diatexite

7
7
7
$P$
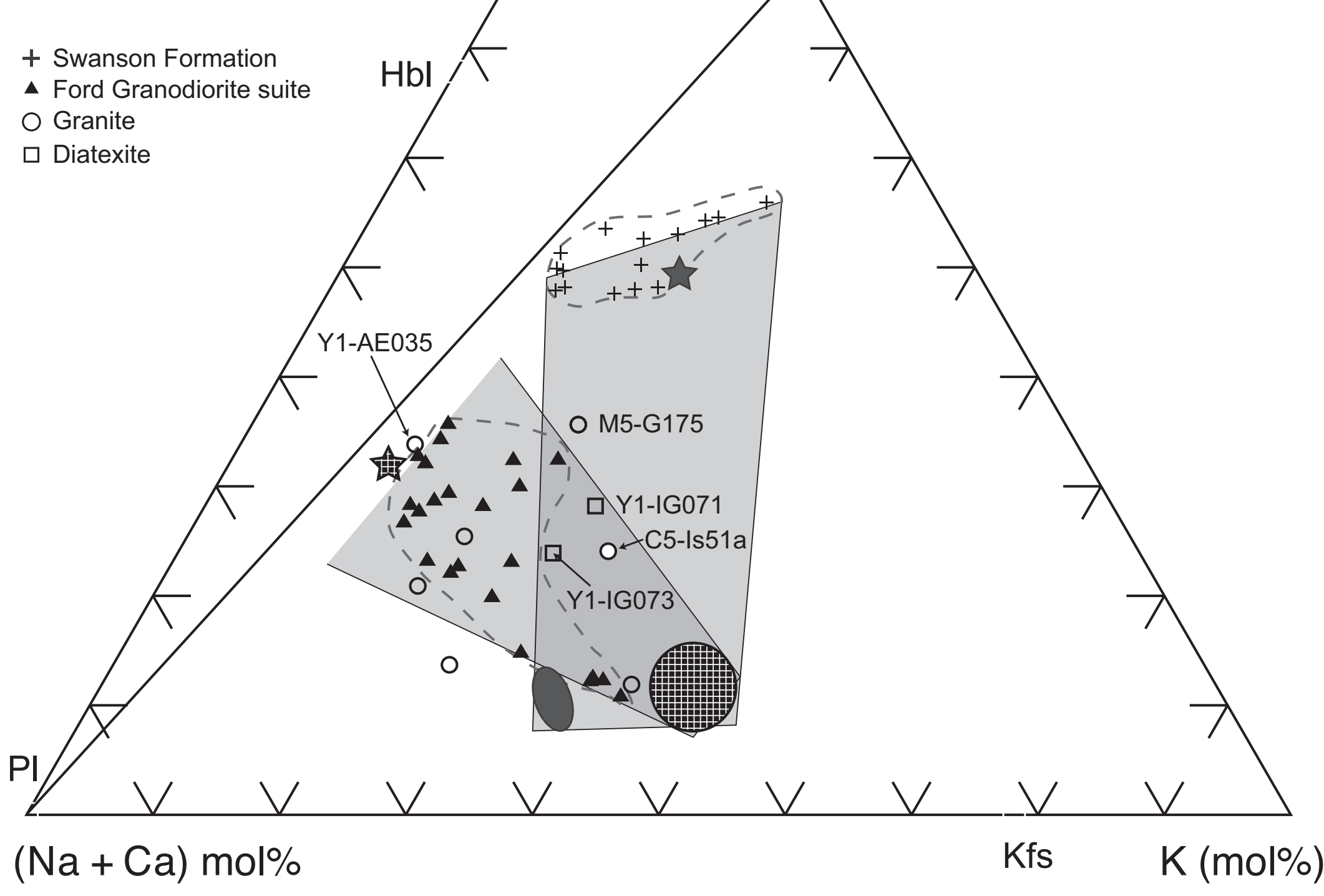

$(\mathrm{Na}+\mathrm{Ca}) \mathrm{mol} \%$
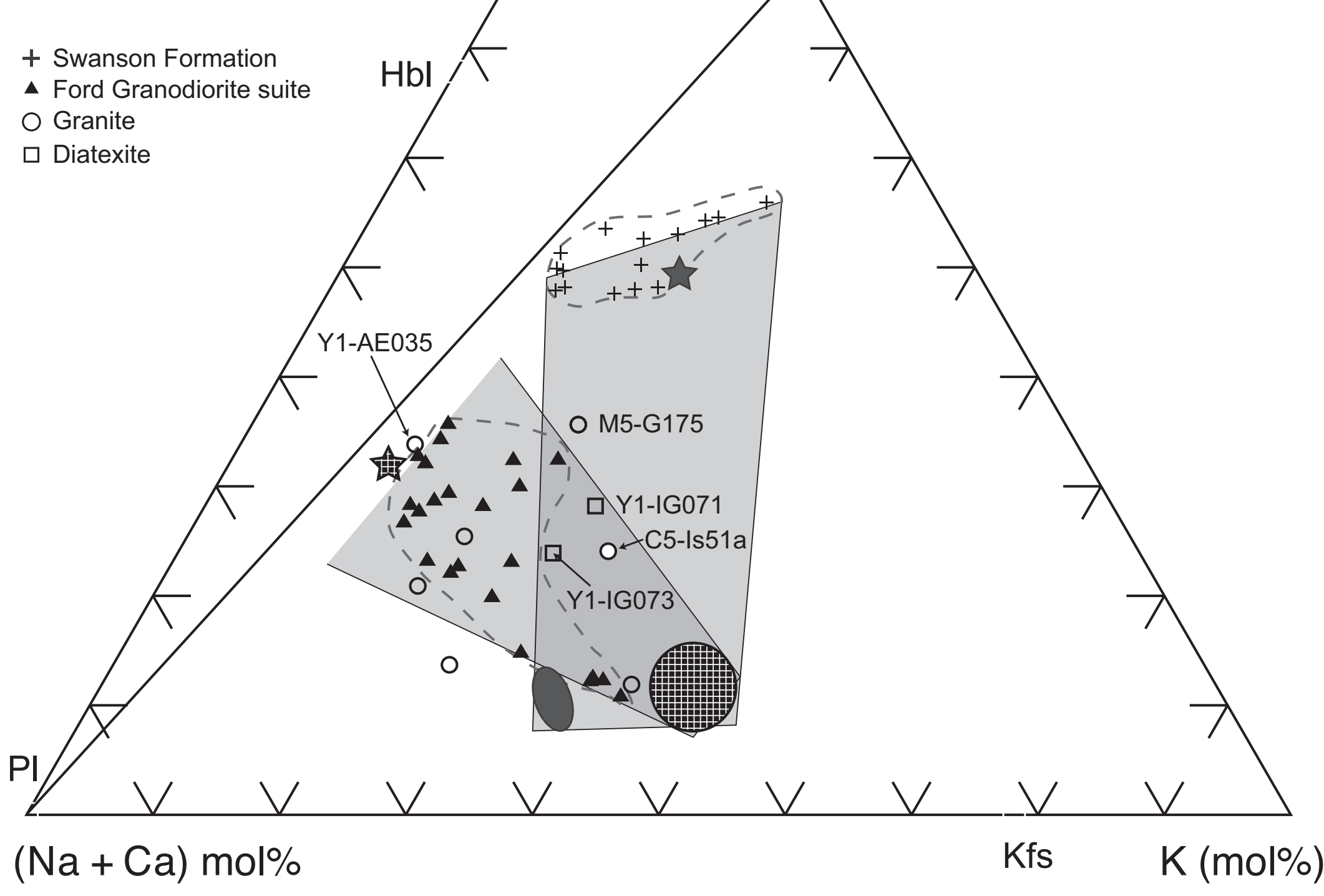

Kfs
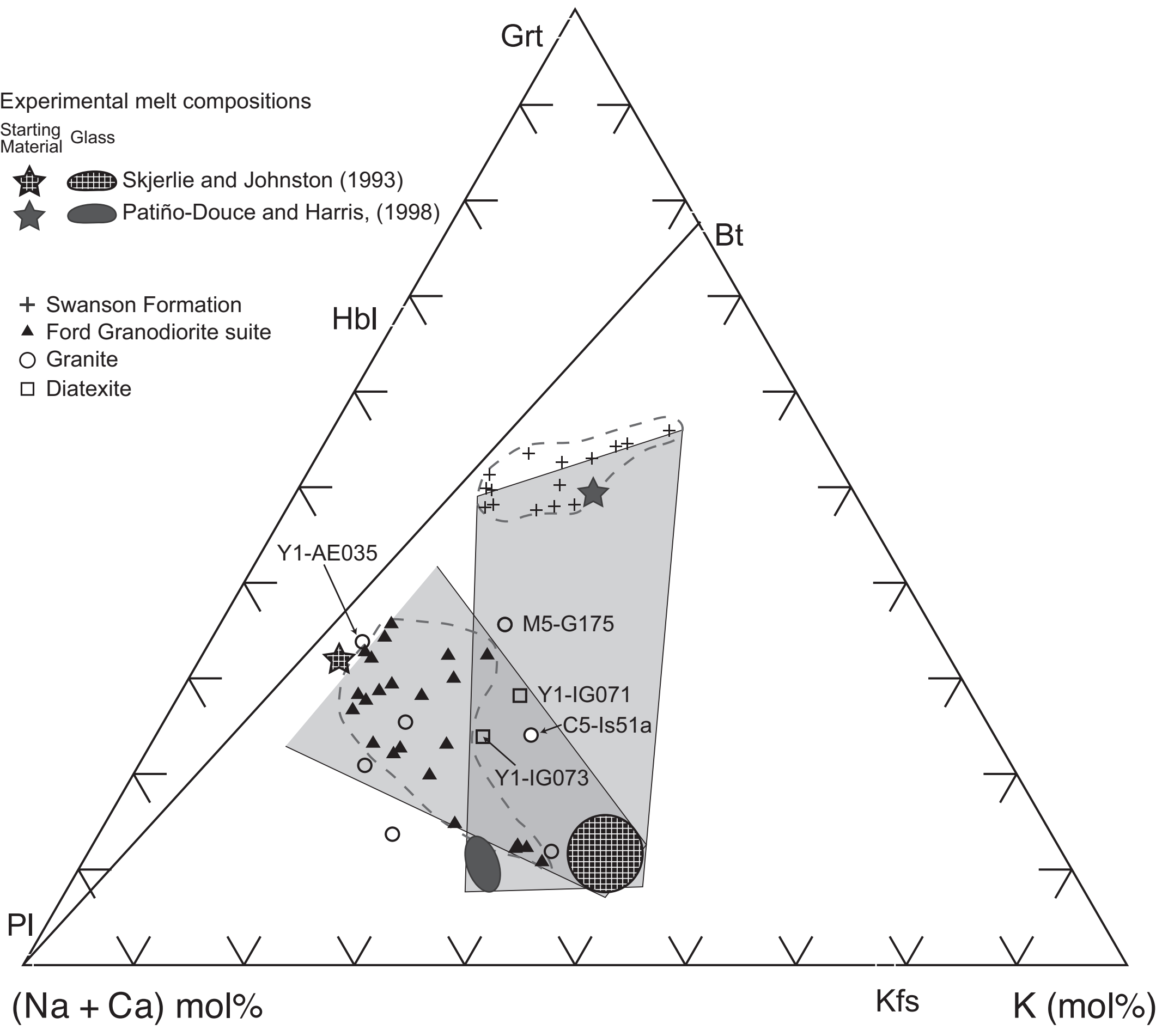

Figure: fig14.eps

Figure 14 Yakymchuk et al. 
Table 1

TABLE 1. ANALYTICAL INFORMATION BY SAMPLE

\begin{tabular}{|c|c|c|c|c|}
\hline & AIVU & U. Arla & zona & U. IVlar viand \\
\hline Sample & U-Pb Hf, O & $\mathrm{U}-\mathrm{Pb}$ & $\mathrm{Hf}$ & \\
\hline
\end{tabular}

Swanson Formation

10CY-001

10CY-002

Y2-BR086

Y2-MD092

Y2-MP098

318-M9

21223-3

21223-8

8D27-10

Ford Granodiorite suite

MB.214

MB.219

$51225-1$

51225-2

Y2-GP091

Y2-HN097

Y2-JU096

Y2-SM095

$\begin{array}{llll} & & \mathrm{x} & \mathrm{x} \\ & & \mathrm{x} & \mathrm{x} \\ & & \mathrm{x} & \mathrm{x} \\ \mathrm{x} & \mathrm{x} & \mathrm{x} & \mathrm{x} \\ \mathrm{x} & \mathrm{x} & \mathrm{x} & \mathrm{x} \\ \mathrm{x} & & & \\ \mathrm{x} & & & \\ \mathrm{x} & & & \\ & & & \end{array}$

Devonian-Carboniferous granite

Y1-AE035

C5-Is51a $\quad X^{*} \quad X^{*}$

$\mathrm{x}$

M5-G175 $\quad x^{*} \quad x^{*}$

$x \quad x$

$\underline{\text { Diatexite }}$

$\begin{array}{llllll}\mathrm{Y} 1-\mathrm{IG} 071 & \mathrm{X} & \mathrm{X} & \mathrm{X} & \mathrm{X} & \mathrm{X}\end{array}$

\begin{tabular}{llllll} 
Y1-IG073 & $x$ & $x$ & $x$ & $x$ & $x$ \\
\hline
\end{tabular}

*Yakymchuk et al. (2013a).

${ }^{\dagger}$ Pankhurst et al. (1998).

${ }^{\S}$ Korhonen et al. (2010a). 
Table 2

TABLE 2. SUMMARY OF U-Pb AGES

\begin{tabular}{|c|c|c|c|c|c|c|c|c|}
\hline $\begin{array}{l}\text { Sample } \\
\end{array}$ & Technique & Rock type & $\overline{\text { Latitude }}$ & $\overline{\text { Longitude }}$ & $\overline{\mathrm{U}-\mathrm{Pb} \text { age }(\mathrm{Ma})}$ & $\overline{\mathrm{MSWD}}$ & $\mathrm{n}$ & Inherited (Ma) \\
\hline Y2-GP091 & LA-ICP-MS & Ford Granodiorite suite & $76^{\circ} 47^{\prime} \mathrm{S}$ & $144^{\circ} 26^{\prime} \mathrm{W}$ & $370.7 \pm 2.8$ & 1.3 & 24 of 25 & \\
\hline $51225-1$ & LA-ICP-MS & Ford Granodiorite suite & $76^{\circ} 40^{\prime} \mathrm{S}$ & $14^{\circ} \mathrm{W}$ & $370.4 \pm 3.9$ & 2.4 & 20 of 24 & \\
\hline Y2-JU096 & SHRIMP & Ford Granodiorite suite & $76^{\circ} 15^{\prime} S$ & $14^{\circ} 16^{\prime} \mathrm{W}$ & $368.3 \pm 2.5$ & 1.5 & 19 of 22 & \\
\hline $51225-2$ & SHRIMP & Ford Granodiorite suite & $76^{\circ} 40^{\prime} S$ & $14^{\circ} \mathrm{W}$ & $364.4 \pm 2.3$ & 1.2 & 21 of 24 & 928,547 \\
\hline 9N27-4 & SHRIMP & Ford Granodiorite suite & $76^{\circ} 8^{\prime} \mathrm{S}$ & $144^{\circ} 2^{\prime} \mathrm{W}$ & $353.5 \pm 2.7$ & 1.8 & 19 of 20 & \\
\hline $912-2 A$ & SHRIMP & Ford Granodiorite suite & $77^{\circ} 10^{\prime} \mathrm{s}$ & $144^{\circ} 48^{\prime} \mathrm{W}$ & $345.3 \pm 2.0$ & 0.51 & 21 of 24 & 523,498 \\
\hline Y1-IG071 & SHRIMP & Diatexite & $76^{\circ} 30^{\prime} \mathrm{S}$ & $145^{\circ} 49^{\prime} \mathrm{W}$ & $376-305$ and $109-104$ & - & - & $2277-542$ \\
\hline Y1-IG073 & LA-ICP-MS & Diatexite & $76^{\circ} 30^{\prime} \mathrm{S}$ & $145^{\circ} 49^{\prime} \mathrm{W}$ & $362.4 \pm 3.7$ & 2.1 & 21 of 24 & \\
\hline Y1-AE035 & LA-ICP-MS & Granite & $76^{\circ} 26^{\prime} S$ & $145^{\circ} 21^{\prime} \mathrm{W}$ & $372.3 \pm 6.0$ & 2.5 & 23 of 24 & \\
\hline
\end{tabular}

